\title{
Effect of Exposure to Soils on the Properties of Asbestos-Cement Pipe
}

\author{
Irving A. Denison and Melvin Romanoff
}

\begin{abstract}
This report summarizes the results of study made on two varieties of asbestos-cement pipe involving the exposure to 15 different soils for periods up to 11 years. The soils range from well-aerated types deficient in water soluble salts to very poorly aerated ones containing high concentrations of soluble material. The effects of exposure to the soils on the mechanical and physical properties of asbestos-cement pipe are indicated by measurements of hydrostatic bursting pressure, crushing strength, water absorption, apparent specific gravity and by observations of the condition of the surface of the specimens removed. Bursting and crushing strengths of the pipe samples, after exposure, were without exception higher than the requirements of the Federal specifications for this class of material.
\end{abstract}

\section{Introduction}

The lack of information on the effect of exposure to different soil conditions on the properties of asbestos-cement pipe prompted the National Bureau of Standards to include two varieties of this material in its comprehensive field investigations of materials for underground construction including ferrous and nonferrous metals $[1,2] .{ }^{1}$ The usual composition of asbestos-cement pipe is four parts of portland cement and one part of asbestos fibers, to which silica flour is sometimes added. In the manufacture of pipe, a felted asbestos-cement sheet, or lamination, is applied continuously to a revolving steel mandrel on which the material is compacted and finishformed under heavy pressure rollers, after which the pipe is subjected to a curing operation. It is used in the United States for transporting water and sewage, farm irrigation, mine drainage, salt water disposal, and for handling industrial process liquids.

In 1937,10 samples of 6 -in. pipe, made by a process to be described, were installed at each of 15 test sites to provide for removal of two samples after each of five periods of exposure. Samples were removed from each site in 1939, 1941, 1946, and 1948 and returned to the laboratory for evaluation of the effect of underground exposure on the properties of the material. On the occasion of the removals in 1939, lengths of 4 -in. pipe, manufactured by a slightly different process, were buried at the same sites. Two samples of this material were removed from each site after exposures of 2, 7, and 9 years. Because it was necessary to discontinue the tests at one site in 1946 , six samples of the 6 -in. pipe and 10 samples of the 4 -in. pipe were removed from this location at that time. Two samples of the 6 -in. pipe and four samples of the 4-in. pipe are currently exposed at each of the other 14 sites.

This report deals with the specimens that were removed after different periods of exposure, up to 11 years for the 6 -in. specimens and up to 9 years for the 4-in. specimens. A brief discussion of the 2 - and 4-year exposures of the 6-in. pipe only, was included in a Bureau circular on underground corro-

\footnotetext{
${ }^{1}$ Figures in brackets indicate the literature references at the end of this paper.
}

sion [3]. Final conclusions of this investigation will be deferred until the completion of examination of the remaining specimens still being exposed.

\section{Properties of the Soils at the Test Sites}

The test sites were selected as representative of a wide variety of soil conditions, as indicated by their chemical and physical properties (table 1). For example, the soils range from extreme acidity, $\mathrm{pH}$ 2.6 to high alkalinity, $\mathrm{pH} 9.4$. Measurements of $\mathrm{pH}$ and total acidity were made on samples of soil shipped from the test sites in sealed containers to prevent drying. This precaution was taken to prevent aeration of certain poorly aerated soils because previous study had shown that oxidation of sulfides to sulfates caused a marked increase in acidity [4]. As a result, the $\mathrm{pH}$ values and total acidity of the soils in table 1 differ from previously reported values [5], which were determined after the soil samples had been dried and pulverized.

The texture of the soils and retentiveness of moisture are indicated relatively by values for the moisture equivalent, that is, the quantity of water retained by a previously saturated soil against a centrifugal force of 1,000 times gravity. Since the true specific gravities of the mineral portions of different soils vary only slightly, the apparent specific gravity, except in the case of organic soils, can be taken as a measure of compactness and hence as a relative measure of porosity. A soil having a very high moisture equivalent and a high specific gravity, such as Acadia clay (soil 51), may be considered to have a very fine texture, high moisture retention, and to be very dense, and impermeable to the flow of air and water. This is confirmed by the poor aeration or drainage of the soil as observed in the field. On the other hand, the sample of Hagerstown loam (soil 55), despite its rather high moisture equivalent (32 percent), is typical of a very porous and well aerated soil, as is indicated by the low apparent specific gravity, 1.49 .

The electrical resistivities of the soils range from $62 \mathrm{ohm}-\mathrm{cm}$, indicating a high concentration of soluble salts, to $17,800 \mathrm{ohm}-\mathrm{cm}$, indicating the practical 
TABle 1. Properties of the soils at the test sites

\begin{tabular}{|c|c|c|c|c|c|c|c|c|c|c|c|c|c|c|c|}
\hline \multicolumn{3}{|c|}{ Test sites } & \multirow{2}{*}{ Aeration } & \multirow{2}{*}{$\begin{array}{l}\text { Mois- } \\
\text { ture } \\
\text { equiv- } \\
\text { alent }\end{array}$} & \multirow{2}{*}{$\begin{array}{c}\text { Ap- } \\
\text { parent } \\
\text { specific } \\
\text { gravity }\end{array}$} & \multirow{2}{*}{$\begin{array}{l}\text { Resist- } \\
\text { ivity at } \\
60^{\circ} \\
\left(15.6^{\circ} \text { C }\right)\end{array}$} & \multirow{2}{*}{$\mathrm{pH}$} & \multirow{2}{*}{$\begin{array}{c}\text { Total } \\
\text { acidity a } \\
\text { (milli- } \\
\text { gram } \\
\text { equiva- } \\
\text { lent per } \\
100 \mathrm{~g} \text { of } \\
\text { soil) }\end{array}$} & \multicolumn{7}{|c|}{$\begin{array}{c}\text { Composition of water extract (milligram equiva- } \\
\text { lent per } 100 \mathrm{~g} \text { of soil) }\end{array}$} \\
\hline $\begin{array}{l}\text { Environment and } \\
\text { soil type }\end{array}$ & Soil & Location & & & & & & & $\begin{array}{l}\mathrm{Na}+\mathrm{K} \\
\text { as } \mathrm{Na}\end{array}$ & $\mathrm{Ca}$ & $\mathrm{Mg}$ & $\mathrm{CO}_{3}$ & $\mathrm{HCO}_{3}$ & $\mathrm{Cl}$ & $\mathrm{SO}_{4}$ \\
\hline \multicolumn{16}{|l|}{ INORGANIC } \\
\hline $\begin{array}{l}\text { Oxidizing acid: } \\
\text { Cecil clay loam..- } \\
\text { Hagerstown loam. } \\
\text { Susquehanna }\end{array}$ & $\begin{array}{l}53 \\
55 \\
62\end{array}$ & $\begin{array}{l}\text { Atlanta, Ga } \\
\text { Lock Raven, Md.. } \\
\text { Meridian, Miss }\end{array}$ & $\begin{array}{l}\text { Good } \\
\text { do } \\
\text { Fair }\end{array}$ & $\begin{array}{c}\text { Percent } \\
33.7 \\
32.0 \\
34.6\end{array}$ & $\begin{array}{l}1.60 \\
1.49 \\
1.79\end{array}$ & $\begin{array}{r}\text { Ohm-em } \\
17,800 \\
5,210 \\
6,920\end{array}$ & $\begin{array}{l}4.8 \\
5.8 \\
4.5\end{array}$ & $\begin{array}{r}5.1 \\
10.9 \\
12.0\end{array}$ & - n ln & -...- & $\cdots$ & $-\cdots$ & (n) & -...- & 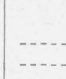 \\
\hline $\begin{array}{l}\text { clay. } \\
\text { Oxidizing, alkaline: }\end{array}$ & & & & & & & & & & & & & & & \\
\hline $\begin{array}{l}\text { Chino silt loam } \\
\text { Mohave fine grav- } \\
\text { elly loam. }\end{array}$ & $\begin{array}{l}65 \\
66\end{array}$ & $\begin{array}{l}\text { Wilmington, Calif } \\
\text { Phoenix, Ariz }\end{array}$ & $\begin{array}{l}\text { Good } \\
\text { Fair }\end{array}$ & $\begin{array}{l}26.4 \\
16.5\end{array}$ & $\begin{array}{l}\text { 1. } 41 \\
1.79\end{array}$ & $\begin{array}{l}148 \\
232\end{array}$ & $\begin{array}{l}\text { 8. } 0 \\
8.0\end{array}$ & $\begin{array}{l}\mathbf{A} \\
\mathbf{A}\end{array}$ & $\begin{array}{l}\text { 7. } 65 \\
6.55\end{array}$ & $\begin{array}{r}12.40 \\
.51\end{array}$ & $\begin{array}{r}2.20 \\
.18\end{array}$ & $\begin{array}{r}0.00 \\
.00\end{array}$ & $\begin{array}{r}1.30 \\
.73\end{array}$ & $\begin{array}{l}6.05 \\
2.77\end{array}$ & $\begin{array}{r}16.90 \\
2.97\end{array}$ \\
\hline $\begin{array}{l}\text { Reducing, acid: } \\
\text { Acadia clay } \\
\text { Sharkey clay }\end{array}$ & $\begin{array}{l}51 \\
61\end{array}$ & $\begin{array}{l}\text { Spindletop, Tex } \\
\text { New Orleans, La.... }\end{array}$ & $\begin{array}{l}\text { Poor } \\
\text { Pdo..... }\end{array}$ & $\begin{array}{l}47.1 \\
30.8\end{array}$ & $\begin{array}{l}\text { 2. } 07 \\
1.78\end{array}$ & $\begin{array}{l}190 \\
943\end{array}$ & $\begin{array}{l}6.2 \\
6.8\end{array}$ & $\begin{array}{r}13.2 \\
4.9\end{array}$ & $\begin{array}{r}10.27 \\
.73\end{array}$ & $\begin{array}{r}15.55 \\
.68\end{array}$ & $\begin{array}{r}5.03 \\
.33\end{array}$ & $\begin{array}{l}.00 \\
.00\end{array}$ & $\begin{array}{l}.56 \\
.71\end{array}$ & $\begin{array}{r}5.75 \\
.10\end{array}$ & $\begin{array}{r}22.00 \\
.91\end{array}$ \\
\hline $\begin{array}{l}\text { Reducing, alkaline: } \\
\text { Docas clay }\end{array}$ & 64 & Cholame, Calif . . & Fair & 41.1 & 1.88 & 62 & 7.5 & A & 28.10 & 2.29 & .76 & .00 & .89 & 28.80 & .26 \\
\hline $\begin{array}{l}\text { Lake Charles } \\
\text { clay. }\end{array}$ & 56 & El Vista, Tex & $\begin{array}{l}\text { Very } \\
\text { poor. }\end{array}$ & 28.7 & 2. 03 & 406 & 7.1 & 5.1 & 3.12 & .69 & .47 & .00 & .80 & 1.59 & 3.04 \\
\hline $\begin{array}{l}\text { Mercedsiltloam } \\
\text { ORGANIC }\end{array}$ & 70 & Buttonwillow, Calif & Fair .... & 24.7 & 1.69 & 278 & 9.4 & A & 8.38 & .38 & .22 & .02 & 1.87 & 1.12 & 5.57 \\
\hline $\begin{array}{l}\text { Reducing, acid: } \\
\text { Carlisle muck }\end{array}$ & 59 & Kalamazoo, Mich_.. & Very & 43.6 & -....- & 1,660 & 5.6 & 12.6 & 1.03 & 3.08 & 2. 70 & .00 & .00 & 3.47 & 1.04 \\
\hline $\begin{array}{l}\text { Muck } \\
\text { Rifle peat }\end{array}$ & $\begin{array}{l}58 \\
60\end{array}$ & $\begin{array}{l}\text { New Orleans, La } \\
\text { Plymouth, Ohio }\end{array}$ & Poor -.. & $\begin{array}{l}57.8 \\
43.4\end{array}$ & $\begin{array}{l}\text { 1. } 43 \\
1.28\end{array}$ & $\begin{array}{l}712 \\
218\end{array}$ & $\begin{array}{l}4.8 \\
2.6\end{array}$ & $\begin{array}{r}15.0 \\
297.4\end{array}$ & $\begin{array}{l}2.03 \\
2.91\end{array}$ & $\begin{array}{r}2.23 \\
10.95\end{array}$ & $\begin{array}{l}\text { 1. } 29 \\
\text { 2. } 86\end{array}$ & $\begin{array}{l}.00 \\
.00\end{array}$ & $\begin{array}{l}.00 \\
.00\end{array}$ & $\begin{array}{l}.47 \\
.00\end{array}$ & $\begin{array}{r}2.54 \\
56.70\end{array}$ \\
\hline Tidal marsh...... & 63 & Charleston, S. C.... & Very & 46.7 & 1. 47 & 84 & 6.9 & 14.6 & 33.60 & 6.85 & 4.00 & .00 & .00 & 12.70 & 36.60 \\
\hline Cinders ...... & 67 & Milwaukee, Wis ... & ... do & -...... & -...... & 455 & 7.6 & A & .77 & 3.03 & .53 & .00 & .55 & .08 & 2.89 \\
\hline
\end{tabular}

a "A" indicates absence of acidity because of alkaline reaction.

absence of such salts (table 1). Other marked differences are indicated by the composition of the water-soluble material in the soils, as for example, the preponderance of chloride in soil 64 and of sulfate in soil 60 .

The soils were classified according to type of environment, as indicated in table 1 . The soils, excepting cinders, are placed in two main divisions depending on whether they are inorganic or organic. The inorganic soils are then divided into two groups according to their oxidizing or reducing nature. Finally, the soils within the groups are classified according to whether they were acid or alkaline. All of the organic soils were reducing and acid in reaction.
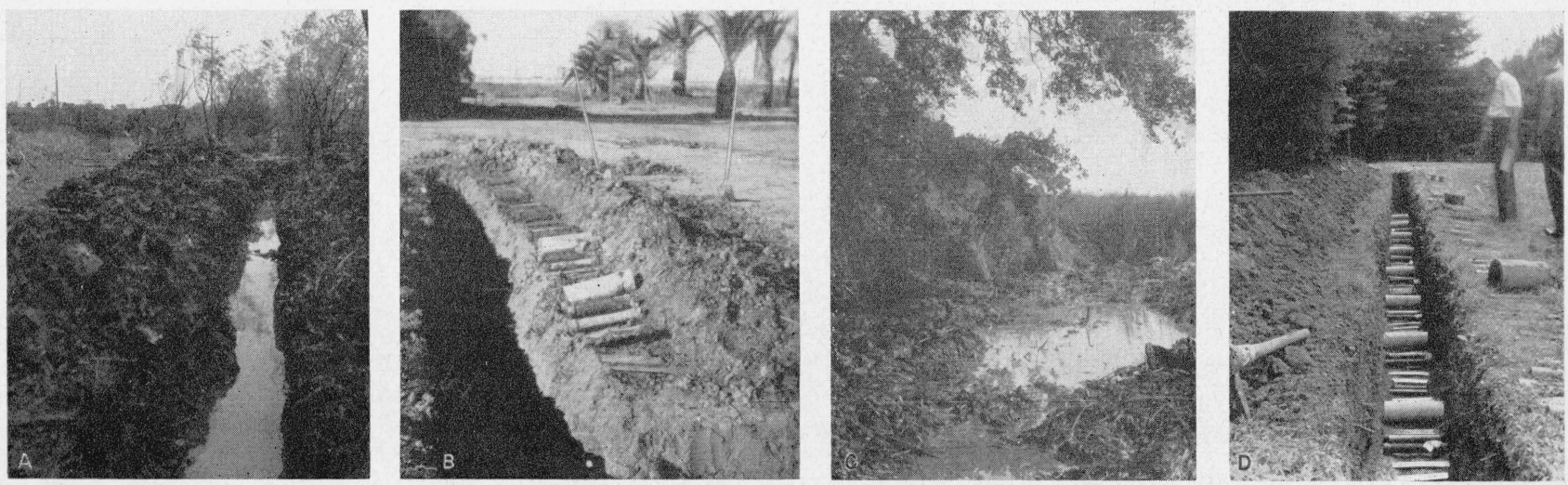

FIGURE 1. Test sites illustrating the environmental conditions to which specimens of asbestos-cement pipe were exposed.

A, Site 56, Lake Charles clay at El Vista, Tex.; B, Site 70, Merced silt loam at Buttonwillow, Calif. C, Site 63 , Tidal marsh at Charleston, S. C.: D, Site 55 , Hagerstown loam at Loch Raven, Md. 
cylinder mold. This sheet, ranging in thickness from 0.010 to 0.020 in., had a width equal to the full length of the pipe sections being manufactured. The sheet was transferred from the mold to an endless felt belt, carried forward over a vacuum chamber to remove excess water, and again transferred to a mandrel on which the pipe was formed continuously until the required wall thickness was attained under heavy compressive force exerted by a system of pressure rollers. The pressure applied during the process was not sufficient to cause any change in the chemical properties or structure of the portland cement.

The 4-in. specimens buried in 1939 were fabricated by essentially the same process, except that the mandrel was held in contact with the felt by compressing rollers. There were six felts, each about $10 \mathrm{~m}$. wide. The mandrel was spiraled helically forward through the machine at the rate of about 1 in. per revolution, and the pipe was built up during this process.

When the required thickness was reached by either process, the seal between the mandrel and the pipe was released by the introduction of air between the mandrel surface and the pipe. This operation, necessarily carried out without the high pressures used while the pipe was being formed, added a small thickness of relatively uncompacted stock to the outside surface. This stock was in excess of the designed wall thickness and is known as the calendar layer. It was noted prior to exposing the specimens at the test sites that the calendar layer was slightly softer than the main body of the pipe.

After removal from the mandrel, the 6-in. pipe was cured by a high-pressure steam process in which heat and pressure were applied to the pipe in a moisture-saturated atmosphere. Silica flour was added to the slurry during the manufacture of these pipes to facilitate the chemical reactions resulting from steam curing. The 4 -in. pipes were cured by submersion in water 2 to 3 weeks, the damp curing process ordinarily used for cement products, after which they were trimmed and machined.

According to the report of the Committee 716 of the American Concrete Institute [6], higher strength properties, more stabilized form, and increased resistance to sulfate are obtainable for masonry cement products with high-pressure steam curing than by the damp curing process. It states that while high strength developed in a few hours of steam curing is in part due to the acceleration of the normal process of hardening, a material contribution to strength comes from the reaction resulting in the formation of a hydrated calcium silicate from the lime and silica present. The more stabilized form of cement attributable to pressure steam curing results, in part, from the conversion (or partial conversion) of the amorphous calcium silicates to crystalline forms, which do not swell or shrink as much as do the amorphous forms with increase or decrease in moisture content. It also has been observed by the Committee that the series of compounds that are known as hydrogarnets, which result from steam curing of cement products, are very stable and highly resistant to the action of sulfate solutions.

The specimens buried in 1937, and for which data are reported for exposures up to 11 years, were cut from class 150 pipe designed to withstand a pressure of $150 \mathrm{lb} / \mathrm{in} .{ }^{2}$. The specimens were $12 \mathrm{in}$. in length, $6 \mathrm{in}$. in diameter, and had an average wall thickness of $0.72 \pm 0.05 \mathrm{in}$. Near one end of each of the specimens was a hole, $3 / 16$ in. in diameter, which was used to hold an identification tag. The ends of the pipe were not sealed, and since it was the intent to limit exposure to the soil to the exterior surface, the interior surface and the ends were coated with a resinous varnish.

The specimens initially buried at the same test sites in 1939, and for which data are reported for exposures up to 9 years, were $4 \mathrm{in}$. in diameter, 15 in. long with an average wall thickness of $0.64 \pm 0.09 \mathrm{in}$. The specimens were tapered $2 \frac{1}{2}$ inches from each end and closures were placed at the junction of the tapered and untapered portions to confine the action of the soil to the external surface. These sections were also cut from class 150 pipe.

\section{Test Procedures}

The specimens as periodically removed were returned to the laboratory for examination of their surfaces and for the determination of their respective hydrostatic bursting strengths, crushing strengths, water absorption, and apparent specific gravity. Five representative samples from each of the 4- and 6-in. "as manufactured" pipe, which were stored at the Bureau, were subjected to the same tests. In addition, a section from each length of pipe from which the 4-in. diameter specimens were cut was subjected to these tests by the manufacturer and the Pittsburgh Testing Laboratory in accordance with the same procedures employed at the Bureau. The determinations made on the unexposed samples were used as reference data in determining the effect of the various soils and periods of exposure on the pipe materials.

In order to simulate service conditions with respect to moisture, the 6 -in. specimens were immersed in water for 48 hours before making the bursting and crushing tests. However, the 4-in. specimens were tested in the air-dry condition because the reference samples had been tested in this condition. In this connection, it may be noted that saturation with water reduces the strength of asbestos-cement pipe from 10 to 20 percent [7]. The details of the procedures employed in evaluating the properties of the exposed and unexposed samples of asbestos-cement follow.

\subsection{Surface Condition}

The depth of softening of the surface was estimated in a semiquantitative manner by scratching or scraping the external surface, allowing for the original condition of the outermost or calendar layers. 
Based on these observations, the condition of the surface was classified according to the following categories: 0, hardening of the calendar layers; 1 , surface unchanged; 2 , softening to a maximum depth of 0.06 in.; 3 , softening to a maximum depth of $0.15 \mathrm{in}$.

During the latter part of the investigation, quantitative measurements of the depth of affected surface layers of the exposed 6-in. diameter specimens were made by the Johns-Manville Research Center by a method recently developed by that laboratory [8]. A section of an exposed specimen was mounted in a precision lathe, and the surface layers, which had been softened by contact with the soil, were removed by grinding under carefully controlled conditions. The grinding operation was continued until the measured hardness was equal to that of unexposed reference asbestos-cement pipe. The thickness of the softened layer was then taken as the difference in thickness between the original and residual wall, as measured with a micrometer or by recording the movement of the graduated compound cross feed of the lathe. In measuring the hardness of the specimen, a cut was made with a tool so designed that the width of the cut varied with the applied load and hardness according to the formula.

$$
\text { Hardness number }=\frac{\text { Applied load }(\mathrm{g}) \times 1000}{\text { Width of } \operatorname{cut}(\mathrm{mm}) \times 0.1} .
$$

Preliminary evaluation of softening of the specimens developed during 9 years of exposure was made on a single stave cut from each specimen, 4 in. along the length of the pipe and $2 \mathrm{in}$. in width. However, the determinations of softening of the specimens exposed for 11 years were made on four staves cut at random from each specimen.

\subsection{Hydrostatic Bursting Pressure}

The 4-in. specimens were prepared for the hydrostatic bursting tests by removing the closures and the tapered ends, the length of the specimens being thereby reduced to 11 in. The 6 -in. specimens required no alteration in their shape or size. The tests were made on only one specimen for each exposure period from each of the test sites, except as noted in the footnote appended to table 2.

The apparatus (fig. 2) for determining the bursting strength was provided with internally fitting rubber gasketed heads to close the ends of the pipe and so designed that the pipe was not subjected to end compression during the test. A vent arrangement for expelling air entrapped in the pipe during test was provided at one of the heads. The opposite head was equipped with a water and pressure inlet, the pressure being provided from a high-pressure hand pump. Backing up of the pressure into the inlet line was prevented by use of suitable check valves.

After filling the pipe with water, the entrapped air was allowed to escape and the pressure was increased at the rate of approximately $\left(10 \mathrm{lb} / \mathrm{in} .^{2}\right) / \mathrm{sec}$

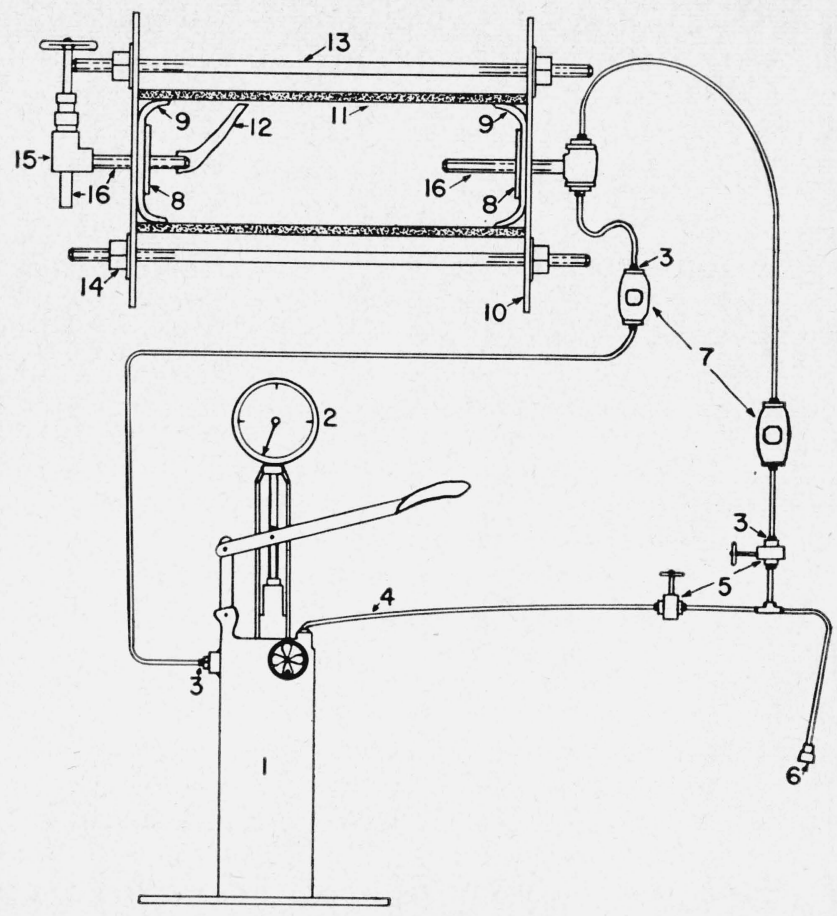

Figure 2. Arrangement of apparatus for hydrostatic bursting tests.

1, Hand-operated hydraulic pump; 2, 'pressure gage; 3, 1/2-in."pipe thread connector with $7 / 16$-in. compression screw for connection to $1 / 4$-in. copper tubing; 4, $1 / 4$-in. copper tubing; $5,1 / 4$-in. needle valve; $6,3 / 4$ - to $1 / 2$-in. reducer for connection to main water supply; 7, 1/4-in. high pressure check valves; 8 , steel disks, $21 / 2$ or $4 \frac{1}{2}$ in. in diameter, which screws on the $3 / 4$-in. threaded pipe to hold the rubber gaskets in place; 9, 4- or 6-in. rubber gaskets for testing the appropriate size of pipe; 10 , steel plates, 9 by 9 by $1 / 2$ in.; 11 , asbestos_cement pipe specimen under test, approximately 12 in. in length; 12 , overflow or air vent; $13,1 / 2$-in. diameter steel rods, threaded on both ends; $14,1 / 2$-in. nut
valve for expelling air; $16,1 / 2$-in. threaded pipe.

until the pipe failed. The pressure gage employed was calibrated before and after the tests for each exposure period, and the bursting pressures shown in tables 2 through 5 are values obtained after applying the correction factor. The corresponding maximum tensile stress values were calculated from the respective bursting pressures.

The minimum, or average, wall thickness along the fracture as well as the location and character of failure of each specimen were noted. Many specimens failed initially by splitting out of a section of the pipe at one end, following which a crack propagated from a point on this fracture along the entire length of the specimen. The others failed by cracking in one or two places simultaneously along the entire length of the specimen. In all but a few cases a crack passed through the hole, which was located near one end of the 6 -in. diameter pipe to hold the identification tag. In the few cases where the crack did not pass through the hole, the bursting pressure values were not noticeably greater than those of the other specimens.

Direct comparison between the bursting pressures of the exposed and unexposed specimens is not valid unless the variations of wall thickness and diameter are taken into account. This was accomplished by computing the maximum tensile strength according 
TABLE 2. Hydrostatic bursting and crushing strength of air-dry specimens of 4-in. asbestos-cement pipe after exposure to soils *

\begin{tabular}{|c|c|c|c|c|c|c|c|c|}
\hline \multicolumn{2}{|r|}{ Soil } & \multirow[b]{2}{*}{ Exposure } & \multicolumn{3}{|c|}{ Bursting strength } & \multicolumn{3}{|c|}{ Crushing strength $\mathrm{b}$} \\
\hline No. & Type & & $\begin{array}{c}\text { Identification } \\
\text { of pipe from } \\
\text { which speci- } \\
\text { men was cut }\end{array}$ & $\begin{array}{l}\text { Bursting } \\
\text { pressure }\end{array}$ & $\begin{array}{c}\text { Maximum } \\
\text { tensile } \\
\text { strength }\end{array}$ & $\begin{array}{l}\text { Identification } \\
\text { of pipe from } \\
\text { which speci- } \\
\text { men was cut }\end{array}$ & $\begin{array}{c}\text { Crushing } \\
\text { load }\end{array}$ & $\begin{array}{l}\text { Modulus } \\
\text { of rupture }\end{array}$ \\
\hline 51 & A cadia clay ..... & $\begin{array}{c}\text { Years } \\
7.0\end{array}$ & $\begin{array}{l}\mathrm{P} \\
\mathrm{I} \\
\mathrm{Q} \\
\mathrm{O} \\
\mathrm{L}\end{array}$ & $\begin{array}{r}l b / i n .^{2} \\
1,300 \\
1,075 \\
775 \\
825 \\
1,075\end{array}$ & $\begin{array}{r}\text { lb/in.2 }{ }^{2} \\
5,210 \\
4,360 \\
3,550 \\
3,600 \\
4,290\end{array}$ & $\begin{array}{l}\mathrm{U} \\
\mathrm{T} \\
\mathrm{P} \\
\mathrm{V} \\
\mathrm{K}\end{array}$ & $\begin{array}{c}\text { lb/linear ft } \\
10,930 \\
13,090 \\
13,060 \\
12,470 \\
12,740\end{array}$ & $\begin{array}{c}l b / \text { in }^{2} \\
11,590 \\
10,510 \\
12,030 \\
10,620 \\
11,010\end{array}$ \\
\hline 53 & Cecil clay loam.... & $\begin{array}{l}1.9 \\
6.8 \\
9.1\end{array}$ & $\begin{array}{l}\mathrm{C} \\
\mathrm{S} \\
\mathrm{V}\end{array}$ & $\begin{array}{l}1,050 \\
1,150 \\
1,245\end{array}$ & $\begin{array}{l}4,070 \\
5,000 \\
4,890\end{array}$ & $\begin{array}{l}\mathrm{T} \\
\mathrm{E} \\
\mathrm{S}\end{array}$ & $\begin{array}{l}10,030 \\
11,440 \\
10,060\end{array}$ & $\begin{array}{r}8,350 \\
9.720 \\
10,890\end{array}$ \\
\hline 55 & Hagerstown loam... & $\begin{array}{l}2.0 \\
7.1 \\
9.1\end{array}$ & $\begin{array}{l}\mathrm{S} \\
\mathrm{O} \\
\mathrm{C}\end{array}$ & $\begin{array}{r}1,000 \\
1,000 \\
885\end{array}$ & $\begin{array}{l}4,120 \\
4,590 \\
3,680\end{array}$ & $\begin{array}{l}\mathrm{G} \\
\mathrm{J} \\
\mathrm{F}\end{array}$ & $\begin{array}{l}12,930 \\
13,240 \\
16,080\end{array}$ & $\begin{array}{l}11,190 \\
11,510 \\
11,030\end{array}$ \\
\hline 56 & Lake Charles clay... & $\begin{array}{l}1.9 \\
6.8 \\
9.1\end{array}$ & $\begin{array}{l}\mathrm{T} \\
\mathrm{N} \\
\mathrm{N}\end{array}$ & $\begin{array}{r}1,250 \\
1,200 \\
950\end{array}$ & $\begin{array}{l}4,750 \\
4,720 \\
3,970\end{array}$ & $\begin{array}{l}\mathrm{H} \\
\mathrm{F} \\
\mathrm{J}\end{array}$ & $\begin{array}{l}12,400 \\
16,660 \\
12,310\end{array}$ & $\begin{array}{r}9,030 \\
12,650 \\
10,700\end{array}$ \\
\hline 58 & Muck & $\begin{array}{l}1.9 \\
6.8 \\
9.1\end{array}$ & $\begin{array}{l}\text { V } \\
\text { I } \\
\text { J }\end{array}$ & $\begin{array}{l}1,275 \\
1,425 \\
1,290\end{array}$ & $\begin{array}{l}5,060 \\
5,500 \\
5,000\end{array}$ & $\begin{array}{l}\mathrm{R} \\
\mathrm{K} \\
\mathrm{T}\end{array}$ & $\begin{array}{l}11,340 \\
13,910 \\
13,180\end{array}$ & $\begin{array}{r}8,820 \\
12,290 \\
10,280\end{array}$ \\
\hline 59 & Carlisle muck ... & $\begin{array}{l}1.9 \\
7.0 \\
9.0\end{array}$ & $\underset{\mathrm{C}}{\mathrm{U}}$ & $\begin{array}{l}1,350 \\
1,200 \\
1,000\end{array}$ & $\begin{array}{l}5,610 \\
4,860 \\
4,040\end{array}$ & $\begin{array}{l}\mathrm{Q} \\
\mathrm{B} \\
\mathrm{S}\end{array}$ & $\begin{array}{r}7,730 \\
13,120 \\
9,980\end{array}$ & $\begin{array}{r}8,660 \\
11,350 \\
9,440\end{array}$ \\
\hline 60 & Rifle peat..... & $\begin{array}{l}1.9 \\
7.0 \\
9.0\end{array}$ & $\begin{array}{l}\mathrm{M} \\
\mathrm{G} \\
\mathrm{A}\end{array}$ & $\begin{array}{r}1,250 \\
1,375 \\
950\end{array}$ & $\begin{array}{l}4,690 \\
5,490 \\
3,950\end{array}$ & $\begin{array}{l}\mathrm{H} \\
\mathrm{D} \\
\mathrm{B}\end{array}$ & $\begin{array}{r}12,890 \\
8,500 \\
10,530\end{array}$ & $\begin{array}{l}8,680 \\
7,510 \\
8,170\end{array}$ \\
\hline 61 & Sharkey clay & $\begin{array}{l}1.9 \\
6.8 \\
9.1\end{array}$ & $\begin{array}{l}\mathrm{E} \\
\mathrm{H} \\
\mathrm{W}\end{array}$ & $\begin{array}{l}1,375 \\
1,350 \\
1,100\end{array}$ & $\begin{array}{l}5,490 \\
4,850 \\
4,110\end{array}$ & $\begin{array}{l}\mathrm{A} \\
\mathrm{U} \\
\mathrm{Q}\end{array}$ & $\begin{array}{r}7,990 \\
12,710 \\
10,330\end{array}$ & $\begin{array}{r}9,940 \\
11,770 \\
10,230\end{array}$ \\
\hline 62 & Susquehanna clay.. & $\begin{array}{l}1.9 \\
6.8 \\
9.1\end{array}$ & $\begin{array}{l}\mathrm{O} \\
\mathrm{Q} \\
\mathrm{L}\end{array}$ & $\begin{array}{r}800 \\
975 \\
1,195\end{array}$ & $\begin{array}{l}3,680 \\
3,950 \\
4,740\end{array}$ & $\begin{array}{l}\mathrm{P} \\
\mathrm{C} \\
\mathrm{W}\end{array}$ & $\begin{array}{l}10,440 \\
12,730 \\
12,750\end{array}$ & $\begin{array}{r}9,360 \\
11,340 \\
9,170\end{array}$ \\
\hline 63 & Tidal marsh... & $\begin{array}{l}1.9 \\
6.7 \\
9.0\end{array}$ & $\begin{array}{l}\mathrm{L} \\
\mathrm{E} \\
\mathrm{U}\end{array}$ & $\begin{array}{l}1,125 \\
1,200 \\
1,100\end{array}$ & $\begin{array}{l}4,350 \\
4,830 \\
4,440\end{array}$ & $\begin{array}{l}\mathrm{H} \\
\mathrm{E} \\
\mathrm{L}\end{array}$ & $\begin{array}{l}14,410 \\
12,860 \\
12,160\end{array}$ & $\begin{array}{r}9,630 \\
10,780 \\
10,580\end{array}$ \\
\hline 64 & Docas clay .... & $\begin{array}{l}1.9 \\
6.9 \\
9.1\end{array}$ & $\begin{array}{l}\mathbf{J} \\
\mathbf{I} \\
\mathbf{J}\end{array}$ & $\begin{array}{l}1,400 \\
1,125 \\
1,340\end{array}$ & $\begin{array}{l}5,530 \\
4,590 \\
5,330\end{array}$ & $\begin{array}{l}\mathrm{G} \\
\mathrm{S} \\
\mathrm{L}\end{array}$ & $\begin{array}{l}12,330 \\
13,760 \\
13,460\end{array}$ & $\begin{array}{l}10,440 \\
11,730 \\
12,450\end{array}$ \\
\hline 65 & Chino silt loam .. & $\begin{array}{l}1.9 \\
6.9 \\
9.1\end{array}$ & $\begin{array}{l}\mathrm{K} \\
\mathrm{Q} \\
\mathrm{U}\end{array}$ & $\begin{array}{l}1,100 \\
1,075 \\
1,195\end{array}$ & $\begin{array}{l}4,460 \\
4,320 \\
4,710\end{array}$ & $\begin{array}{l}M \\
D \\
B\end{array}$ & $\begin{array}{l}12,900 \\
10,090 \\
16,630\end{array}$ & $\begin{array}{r}9,780 \\
9,540 \\
12,890\end{array}$ \\
\hline 66 & Mohave fine gravelly loam & $\begin{array}{l}1.9 \\
6.9 \\
9.1\end{array}$ & $\begin{array}{l}\text { D } \\
\text { I } \\
\text { E }\end{array}$ & $\begin{array}{l}1,100 \\
1,350 \\
1,245\end{array}$ & $\begin{array}{l}4,410 \\
5,420 \\
4,860\end{array}$ & $\begin{array}{l}\mathrm{P} \\
\mathrm{T} \\
\mathrm{T}\end{array}$ & $\begin{array}{l}11,190 \\
14,180 \\
12,460\end{array}$ & $\begin{array}{r}9,910 \\
10,510 \\
9,590\end{array}$ \\
\hline 67 & Cinders .... & $\begin{array}{l}1.9 \\
7.0 \\
9.0\end{array}$ & $\begin{array}{l}\mathrm{O} \\
\mathrm{R} \\
\mathrm{S}\end{array}$ & $\begin{array}{r}800 \\
1,325 \\
1,245\end{array}$ & $\begin{array}{l}3,560 \\
4,840 \\
4,870\end{array}$ & $\begin{array}{l}\mathrm{A} \\
\mathrm{F} \\
\mathrm{Q}\end{array}$ & $\begin{array}{r}9,570 \\
12,210 \\
8,010\end{array}$ & $\begin{array}{l}9,850 \\
9,560 \\
7,970\end{array}$ \\
\hline 70 & Merced silt loam... & $\begin{array}{l}1.9 \\
6.9 \\
9.1\end{array}$ & $\begin{array}{l}\mathrm{F} \\
\mathrm{M} \\
\mathrm{R}\end{array}$ & $\begin{array}{l}1,425 \\
1,375 \\
1,340\end{array}$ & $\begin{array}{l}5,420 \\
5,140 \\
4,940\end{array}$ & $\begin{array}{l}\mathrm{P} \\
\mathrm{D} \\
\mathrm{S}\end{array}$ & $\begin{array}{r}11,310 \\
8,260 \\
14,630\end{array}$ & $\begin{array}{r}10,000 \\
8,230 \\
11,970\end{array}$ \\
\hline
\end{tabular}

a A verage dimensions -internal diameter, $3.99 \pm 0.05$ in.; wall thickness, $0.63 \pm 0.10$ in.; length of samples for crushing tests, $5.13+0.32$ or -0.81 in.; length of samples or bursting tests, 11 in.

b Data are the average of two measurements made on one specimen.

- See table 3 for results of tests on reference (unexposed) specimens.

to the following modification of the Birnie [9] formula adapted to asbestos-cement pipe

where

$$
f=\frac{P(d+1.7 t)}{2 t}
$$

$f=$ maximum tensile strength in pounds per square inch

$P=$ bursting pressure at failure in pounds per square inch

$d=$ internal diameter in inches

$t=$ wall thickness in inches.

\subsection{Crushing Strength}

Determinations of crushing strength were made on lengths of pipe prepared by circumferentially cutting in half one specimen for each exposure period from each site. The values shown in tables 2 to 5 in each case are the averages of those obtained on two samples from each specimen. The tests were made according to the procedure described in Federal Specifications for asbestos-cement pipe [10], using the three-edge bearing method as illustrated in figure 3 . The load was applied to one section at a rate of approximately $1,000 \mathrm{lb} / \mathrm{min}$ until failure 
TABLE 3. Mechanical and physical properties of unexposed specimens of air-dry asbestos-cement pipe 4 in. in diameter a

\begin{tabular}{|c|c|c|c|c|c|c|}
\hline \multirow{2}{*}{$\begin{array}{c}\text { Designation } \\
\text { of original } \\
\text { pipe from } \\
\text { which sec- } \\
\text { tion was } \\
\text { cut }\end{array}$} & \multicolumn{2}{|c|}{ Bursting strength } & \multicolumn{2}{|c|}{ Crushing strength } & \multirow{2}{*}{$\begin{array}{c}\text { Water } \\
\text { absorp_ } \\
\text { tion }\end{array}$} & \multirow{2}{*}{$\begin{array}{l}\text { Apparent } \\
\text { specific } \\
\text { gravity }\end{array}$} \\
\hline & $\begin{array}{l}\text { Bursting } \\
\text { pressure }\end{array}$ & $\begin{array}{c}\text { Maxi_ } \\
\text { mum } \\
\text { tensile } \\
\text { strength }\end{array}$ & $\begin{array}{l}\text { Crush- } \\
\text { ing load }\end{array}$ & $\begin{array}{l}\text { Modulus } \\
\text { of rup- } \\
\text { ture }\end{array}$ & & \\
\hline A. & $\begin{array}{r}l b / \text { in } .2^{2} \\
950\end{array}$ & $\begin{array}{r}l b / \text { in. }^{2} \\
4,070\end{array}$ & $\begin{array}{c}\text { lb/linear } f t \\
9,630\end{array}$ & $\begin{array}{l}\text { lb/in. }{ }^{2} \\
10,130\end{array}$ & $\begin{array}{l}\text { Percent } \\
14.7\end{array}$ & 1.86 \\
\hline & 1,000 & 4,330 & 10,570 & 10,760 & 13.6 & 1. 84 \\
\hline B & 1,120 & 4,440 & 11,770 & 9,410 & 14.1 & 1.86 \\
\hline $\mathrm{B}$ & 1,200 & 4,650 & 100 & & 14.6 & 1.83 \\
\hline C. & 820 & 3,190 & 9,510 & 8,710 & 15. 9 & $\begin{array}{l}1.78 \\
\text {. }\end{array}$ \\
\hline $\mathrm{C}^{-}$ & & ...... & 10,270 & 8,710 & 15.0 & 1.81 \\
\hline $\mathrm{C}$ & $\ldots$ & ....... & 9,150 & 8,340 & 16.0 & 1.84 \\
\hline D. & 730 & 2,960 & 8,760 & 7,900 & 18.0 & 1. 72 \\
\hline $\mathrm{E}$ & 1,020 & 3,940 & 10,050 & 8,760 & 15. 6 & 1.83 \\
\hline $\mathrm{F}$ - & 1,150 & 4,280 & 11,970 & 9,600 & 15. 3 & 1.84 \\
\hline $\mathrm{G}_{-}$ & 1,080 & 4,310 & 10,650 & 9,520 & 16. 7 & 1.80 \\
\hline H. & 1,190 & 4,440 & 13,039 & 8,700 & 15.9 & 1.81 \\
\hline I_ & 1,100 & 4,270 & 10,010 & 8,310 & 17.9 & 1.75 \\
\hline $\mathrm{J}$ & 1,225 & 4,730 & 12,580 & 10,320 & 15.5 & 1.84 \\
\hline $\mathrm{K}$. & 1,060 & 4,260 & 11,780 & 9,710 & 16.3 & 1.81 \\
\hline & 940 & 3,830 & 10,950 & 9,850 & 16. 0 & 1. 81 \\
\hline $\mathrm{L} \mathrm{b}_{-}$ & 1,100 & 4,570 & & -..... & 15.6 & 1.83 \\
\hline $\mathrm{M}_{-}$ & 1,100 & 4,100 & 11,760 & 8,670 & 16. 5 & 1.81 \\
\hline $\mathrm{N}_{\mathrm{b}}$ & $\begin{array}{r}950 \\
000\end{array}$ & $\begin{array}{l}3,730 \\
3,920\end{array}$ & 12,120 & 9,200 & $\begin{array}{l}16.1 \\
15.5\end{array}$ & $\begin{array}{l}1.80 \\
1.84\end{array}$ \\
\hline O & $\begin{array}{l}1,000 \\
750\end{array}$ & $\begin{array}{l}0,320 \\
3,290\end{array}$ & 7,690 & 8,880 & 17.0 & $\begin{array}{l}1.07 \\
1.74\end{array}$ \\
\hline $\mathrm{P}$ & 1,100 & 4,460 & 10,740 & 9,560 & 14.6 & 1.87 \\
\hline Q. & 790 & 3,360 & 8,390 & 8,110 & 16. 3 & 1.78 \\
\hline $\mathrm{R}$ & 1,000 & 3,720 & 9,050 & 8,360 & 15. 9 & 1. 79 \\
\hline $\mathrm{S}$ & 1,050 & 4,260 & 11,100 & 8,470 & 13.5 & 1.85 \\
\hline $\mathrm{T}$ & 1,100 & 4,280 & 9,850 & 8,140 & 13.1 & 1.84 \\
\hline U..... & 1,000 & 4,110 & 11,240 & 8,950 & $13: 9$ & 1.87 \\
\hline & 1,050 & 4,120 & 9,600 & 7,460 & 14.5 & \\
\hline $\mathrm{W}$ & 750 & 2,860 & 9,910 & 8,450 & 14.6 & 1.81 \\
\hline & 950 & 3,700 & 10,380 & 7,670 & 13.5 & 1.85 \\
\hline
\end{tabular}

r a A verage dimensions-internal diameter, $3.99 \pm 0.05$ in.; wall thickness, $0.64 \pm$ $0.09 \mathrm{in}$.; length of samples for crushing tests, $4.13+0.75$ or -0.18 in.; length of samples for bursting tests, 11 in.

b Measurements made by the National Bureau of Standards. Measurements on the other reference specimens were made by the Pittsburgh Testing Laboratories and the research laboratories of the manufacturer.

TABLE 4. Hydrostatic bursting and crushing strength of water-saturated 6-in. asbestos-cement pipe after exposure to soils a

\begin{tabular}{|c|c|c|c|c|c|c|}
\hline \multicolumn{2}{|r|}{ Soil } & \multirow{2}{*}{$\begin{array}{c}\text { Ex- } \\
\text { posure }\end{array}$} & \multicolumn{2}{|c|}{$\begin{array}{l}\text { Bursting } \\
\text { strength b }\end{array}$} & \multicolumn{2}{|c|}{$\begin{array}{l}\text { Crushing } \\
\text { strength }{ }^{\circ}\end{array}$} \\
\hline No. & Type & & $\begin{array}{c}\text { Burst- } \\
\text { ing } \\
\text { pres- } \\
\text { sure }\end{array}$ & $\begin{array}{c}\text { Max- } \\
\text { imum } \\
\text { tensile } \\
\text { strength }\end{array}$ & $\begin{array}{c}\text { Crush- } \\
\text { ing } \\
\text { load }\end{array}$ & $\begin{array}{l}\text { Modu- } \\
\text { lus of } \\
\text { rupture }\end{array}$ \\
\hline 51 & Acadia clay .. & $\begin{array}{c}\text { Years } \\
2.1 \\
\text { d } 9.0\end{array}$ & $\begin{array}{c}\text { lb/in. } .^{2} \\
995 \\
1,025\end{array}$ & $\begin{array}{l}l b / i n .^{2} \\
4,980 \\
5,130\end{array}$ & $\begin{array}{c}\text { lb/linear } \\
f t \\
12,440 \\
10,170\end{array}$ & $\begin{array}{c}\mathrm{lb} / \mathrm{in} .^{2} \\
10,770 \\
9,800\end{array}$ \\
\hline 53 & Cecil clay loam.. & $\begin{array}{r}2.1 \\
4.0 \\
8.9 \\
11.2\end{array}$ & $\begin{array}{r}1,140 \\
1,010 \\
950 \\
1,000\end{array}$ & $\begin{array}{l}5,460 \\
5,080 \\
4,860 \\
4,860\end{array}$ & $\begin{array}{l}14,150 \\
10,840 \\
11,120 \\
13,480\end{array}$ & $\begin{array}{l}13,630 \\
10,970 \\
11,630 \\
13,340\end{array}$ \\
\hline 55 & Hagerstown loam & $\begin{array}{r}1.9 \\
3.9 \\
9.0 \\
11.0\end{array}$ & $\begin{array}{r}1,085 \\
1,100 \\
1,150 \\
910\end{array}$ & $\begin{array}{l}5,400 \\
5,450 \\
5,820 \\
4,420\end{array}$ & $\begin{array}{l}12,130 \\
12,870 \\
10,290 \\
13,180\end{array}$ & $\begin{array}{r}12,560 \\
13,030 \\
9,890 \\
11,450\end{array}$ \\
\hline 56 & , Lake Charles clay & $\left\{\begin{array}{r}2.1 \\
4.0 \\
8.9 \\
11.1\end{array}\right.$ & $\begin{array}{r}995 \\
1,050 \\
1,050 \\
935\end{array}$ & $\begin{array}{l}5,070 \\
5,160 \\
5,410 \\
4,600\end{array}$ & $\begin{array}{r}13,140 \\
12,590 \\
9,260 \\
10,500\end{array}$ & $\begin{array}{r}13,010 \\
12,810 \\
9,650 \\
10,990\end{array}$ \\
\hline 58 & Muck ... & $\begin{array}{r}2.1 \\
4.0 \\
8.9 \\
11.2\end{array}$ & $\begin{array}{r}1,140 \\
925 \\
-855\end{array}$ & $\begin{array}{l}5,560 \\
4,630 \\
4,520\end{array}$ & $\begin{array}{r}12,760 \\
12,260 \\
7,850 \\
9,220\end{array}$ & $\begin{array}{r}12,570 \\
11,230 \\
9,240 \\
9,390\end{array}$ \\
\hline$\stackrel{\bullet}{59}$ & Carlisle muck - & $\left\{\begin{array}{r}2.1 \\
4.0 \\
9.1 \\
11.1\end{array}\right.$ & $\begin{array}{l}1,255 \\
1,215 \\
1,125 \\
1,100\end{array}$ & $\begin{array}{l}6,070 \\
6,340 \\
5,830 \\
5,300\end{array}$ & $\begin{array}{l}12,050 \\
11,730 \\
11,540 \\
11,300\end{array}$ & $\begin{array}{l}12,200 \\
11,540 \\
10,530 \\
10,900\end{array}$ \\
\hline
\end{tabular}

TABLE 4. Hydrostatic bursting and crushing strength of water-saturated 6-in. asbestos-cement pipe after exposure to soils a-Continued

\begin{tabular}{|c|c|c|c|c|c|c|}
\hline \multicolumn{2}{|r|}{ Soil } & \multirow{2}{*}{$\begin{array}{c}\text { Ex- } \\
\text { posure }\end{array}$} & \multicolumn{2}{|c|}{$\begin{array}{l}\text { Bursting } \\
\text { strength b }\end{array}$} & \multicolumn{2}{|c|}{$\begin{array}{l}\text { Crushing } \\
\text { strength e }\end{array}$} \\
\hline No. & Type & & $\begin{array}{l}\text { Burst- } \\
\text { ing } \\
\text { pres- } \\
\text { sure }\end{array}$ & $\begin{array}{c}\text { Max- } \\
\text { imum } \\
\text { tensile } \\
\text { strength }\end{array}$ & $\begin{array}{c}\text { Crush- } \\
\text { ing } \\
\text { load }\end{array}$ & $\begin{array}{l}\text { Modu- } \\
\text { lus of } \\
\text { rupture }\end{array}$ \\
\hline 60 & Rifle peat.. & $\begin{array}{c}\text { Years } \\
\left\{\begin{array}{c}2.1 \\
4.0 \\
9.1 \\
11.1\end{array}\right.\end{array}$ & $\begin{array}{l}\mathrm{lb} / \mathrm{in} .^{2} \\
1,010 \\
1,165 \\
1,125 \\
1,050\end{array}$ & $\begin{array}{l}\text { lb/in. }{ }^{2} \\
5,080 \\
5,770 \\
5,760 \\
5,220\end{array}$ & $\begin{array}{c}\text { lb/linear } \\
f t \\
12,120 \\
12,120 \\
9,920 \\
9,790\end{array}$ & $\begin{array}{c}\text { lb/in. } .^{2} \\
11,970 \\
11,330 \\
10,070 \\
9,410\end{array}$ \\
\hline 61 & Sharkey clay ........ & $\left\{\begin{array}{r}2.1 \\
4.0 \\
8.9 \\
11.2\end{array}\right.$ & $\begin{array}{r}1,205 \\
1,065 \\
975 \\
1,000\end{array}$ & $\begin{array}{l}6,040 \\
5,330 \\
4,870 \\
4,760\end{array}$ & $\begin{array}{r}14,930 \\
9,690 \\
9,990 \\
9,420\end{array}$ & $\begin{array}{r}13,960 \\
10,710 \\
9,600 \\
9,530\end{array}$ \\
\hline 62 & Susquehanna clay... & $\left\{\begin{array}{r}2.1 \\
4.0 \\
8.9 \\
11.2\end{array}\right.$ & $\begin{array}{r}1,095 \\
1,125 \\
900 \\
1,125\end{array}$ & $\begin{array}{l}5,410 \\
5,700 \\
4,570 \\
5,450\end{array}$ & $\begin{array}{l}15,650 \\
12,980 \\
10,080 \\
12,700\end{array}$ & $\begin{array}{l}14,460 \\
12,840 \\
10,860 \\
12,630\end{array}$ \\
\hline 63 & Tidal marsh_... & $\left\{\begin{array}{r}2.1 \\
4.0 \\
8.9 \\
11.2\end{array}\right.$ & $\begin{array}{r}1,175 \\
1,150 \\
775 \\
1,000\end{array}$ & $\begin{array}{l}5,620 \\
5,570 \\
4,290 \\
4,940\end{array}$ & $\begin{array}{l}17,370 \\
14,980 \\
11,430 \\
12,720\end{array}$ & $\begin{array}{l}14,680 \\
14,820 \\
10,960 \\
11,960\end{array}$ \\
\hline 64 & Docas clay ... & $\left\{\begin{array}{r}2.1 \\
4.0 \\
9.0 \\
11.2\end{array}\right.$ & $\begin{array}{r}1,100 \\
1,150 \\
750 \\
1,195\end{array}$ & $\begin{array}{l}5,810 \\
5,570 \\
3,930 \\
5,890\end{array}$ & $\begin{array}{l}14,410 \\
15,290 \\
11,750 \\
11,600\end{array}$ & $\begin{array}{l}13,900 \\
14,290 \\
11,930 \\
10,650\end{array}$ \\
\hline 65 & Chino silt loam & $\left\{\begin{array}{r}2.1 \\
4.0 \\
9.0 \\
11.2\end{array}\right.$ & $\begin{array}{r}935 \\
1,070 \\
975 \\
1,125\end{array}$ & $\begin{array}{l}4,800 \\
5,420 \\
4,990 \\
5,400\end{array}$ & $\begin{array}{l}15,980 \\
13,160 \\
11,680 \\
13,650\end{array}$ & $\begin{array}{l}15,750 \\
12,300 \\
11,290 \\
12,640\end{array}$ \\
\hline 66 & $\begin{array}{l}\text { Mohave fine gravelly } \\
\text { loam }\end{array}$ & $\left\{\begin{array}{r}2.1 \\
4.0 \\
9.0 \\
11.2\end{array}\right.$ & $\begin{array}{l}1,215 \\
1,240 \\
1,075 \\
1,100\end{array}$ & $\begin{array}{l}5,820 \\
6,210 \\
5,470 \\
5,400\end{array}$ & $\begin{array}{l}14,500 \\
13,680 \\
11,110 \\
-.--\end{array}$ & $\begin{array}{l}13,900 \\
14,170 \\
10,710 \\
. . .-\end{array}$ \\
\hline 67 & Cinders... & $\left\{\begin{array}{r}2.1 \\
4.0 \\
9.0 \\
11.1\end{array}\right.$ & $\begin{array}{r}1,030 \\
1,105 \\
675 \\
910\end{array}$ & $\begin{array}{l}5,100 \\
5,410 \\
3,570 \\
4,680\end{array}$ & $\begin{array}{r}15,650 \\
11,140 \\
11,275 \\
9,700\end{array}$ & $\begin{array}{r}14,680 \\
11,320 \\
11,430 \\
9,840\end{array}$ \\
\hline 70 & Merced silt loam .... & $\left\{\begin{array}{r}2.1 \\
4.0 \\
11.2\end{array}\right.$ & $\begin{array}{l}1,155 \\
1,285 \\
1,025\end{array}$ & $\begin{array}{l}5,720 \\
6,020 \\
5,220\end{array}$ & $\begin{array}{l}13,180 \\
14,260 \\
12,790\end{array}$ & $\begin{array}{l}13,380 \\
13,330 \\
12,730\end{array}$ \\
\hline
\end{tabular}

a Average dimensions - internal diameter, $5.93 \pm 0.07$ in.; wall thickness, $0.72 \pm$ 0.05 in.; length of samples for crushing tests, $5.86 \pm .013$ in.; length of samples for bursting tests, 12 in.

b Data are for one specimen only except as noted.

c Data are for two specimens only except as noted.

d A verage of measurements on four specimens.

TABLE 5. Mechanical and physical properties of unexposed specimens of water-saturated asbestos-cement pipe 6 in. in diameter a $^{\text {a }}$

\begin{tabular}{|c|c|c|c|c|c|c|}
\hline Specimen & $\begin{array}{l}\text { Bursting } \\
\text { pressure }\end{array}$ & $\begin{array}{c}\text { Max- } \\
\text { imum } \\
\text { tensile } \\
\text { strength }\end{array}$ & $\begin{array}{c}\text { Crush- } \\
\text { ing } \\
\text { load }\end{array}$ & $\begin{array}{l}\text { Modulus } \\
\text { of } \\
\text { rupture }\end{array}$ & $\begin{array}{l}\text { Water } \\
\text { absorp- } \\
\text { tion }\end{array}$ & $\begin{array}{l}\text { Apparent } \\
\text { specific } \\
\text { gravity }\end{array}$ \\
\hline $\begin{array}{l}1 \\
2 \\
3 \\
4 \mathrm{a} \\
4 \mathrm{~b} \\
5 \mathrm{a} \\
5 \mathrm{~b}\end{array}$ & $\begin{array}{r}\text { lb/in. }{ }^{2} \\
995 \\
940 \\
970 \\
\\
\end{array}$ & \begin{tabular}{r} 
lb/in. ${ }^{2}$ \\
5,010 \\
4,670 \\
4,750 \\
- \\
\hdashline \\
\end{tabular} & $\begin{array}{c}\text { lb/linear } \\
f t\end{array}$ & $\begin{array}{l}l b / \text { in }^{2} \\
10,160 \\
10,470 \\
11,660 \\
10,360\end{array}$ & $\begin{array}{c}\text { Percent } \\
9.6 \\
10.9 \\
10.0 \\
9.6 \\
9.1 \\
9.6 \\
9.8\end{array}$ & $\begin{array}{l}1.81 \\
1.88 \\
1.93 \\
1.92 \\
1.90 \\
1.90 \\
1.93\end{array}$ \\
\hline Average & 990 & 4,810 & 10,640 & 10,660 & 9.8 & 1. 90 \\
\hline
\end{tabular}

a Average dimensions: internal diameter, $5.94 \pm 0.03$ in.; wall thickness, $0.71 \pm$ $0.01 \mathrm{in}$; length of samples for crushing tests, $5.81 \pm 0.23$ in.; length of samples for bursting tests, 12 in. 


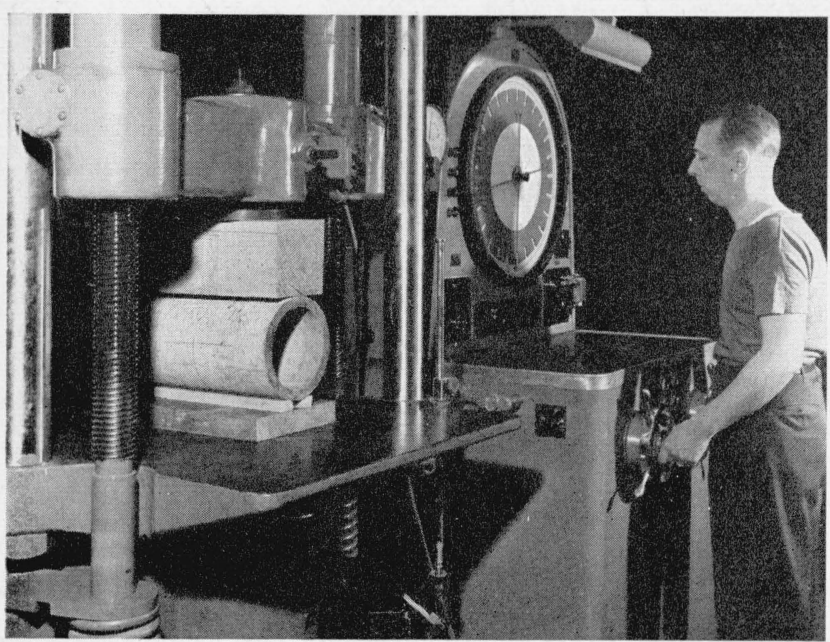

Figure 3. Determination of crushing strength of section of asbestos-cement pipe.

occurred and similarly applied to the other section of the same specimen rotated through $90^{\circ}$.

In order to take into account the normal dimensional variations in comparing the crushing strengths of the exposed and unexposed specimens, the modulus of rupture of the individual specimens was calculated from the values of crushing strength according to the formula given below. This formula, which is used generally in the asbestos-cement industry, is obtained by combining the standard ASTM formulas for crushing tests for application to the three-edge bearing method.

where

$$
f=\frac{0.9 P(d+t)}{L t^{2}},
$$

$f=$ modulus of rupture in pounds per square inch

$P=$ load to produce failure in pounds

$d=$ internal diameter in inches

$t=$ wall thickness in inches

$L=$ length in inches.

\subsection{Water Absorption and Apparent Specific Gravity}

After completion of the bursting and crushing tests, samples, approximately $4 \mathrm{in}$. in length and 2 in. in width, were cut from sound sections of the tested specimens for water absorption and apparent specific gravity determinations. Air-dried samples were immersed in water for 24 hours and weighed in water and in air, respectively. The specimens then were dried at $105^{\circ} \mathrm{C}$ until a constant weight was obtained. The percentage of moisture absorbed and the apparent specific gravity were calculated as follows: Water absorption (in percent) $=$

$$
\frac{\text { (wet weight in air) }-(\text { dry weight })}{\text { dry weight }} \times 100,
$$

Apparent specific gravity $=$

$$
\text { dry weight }
$$

(wet weight in air)-(wet weight in water)

\section{Results}

\subsection{Hydrostatic Bursting Pressure and Crushing Strength}

The results of hydraulic bursting pressure and crushing strength tests, which were made on the 4-in. specimens after exposure at the test sites for three periods, are given in table 2. Corresponding data for the reference specimens, together with values for water absorption and apparent specific gravity, are given in table 3 . The letter symbols identifying the particular pipe from which the specimens were cut, permit comparison of the strengths of the exposed and unexposed specimens with a minimum of error due to normal variability of the material. As was previously noted, these measurements were made on the specimens in the air-dry condition.

The values for bursting pressure and crushing strength of the 6 -in. specimens exposed at the test sites for four periods and the properties of the reference specimens are given in tables 4 and 5, respectively. Unlike the determinations made on the 4 -in. pipe, these were made on water-saturated specimens. Because the particular pipes from which the 6 -in. specimens were cut were not identified it is necessary to make use of the average values given in table 5 in evaluating the effects of exposure to the soils.

The data for the exposed specimens of 4- and 6-in. pipe, recorded in tables 2 and 4 , show that for the maximum exposures of 9 and 11 years the bursting and crushing strengths of the specimens were without exception much higher than the requirements of the Federal Specifications for this class of material.

Federal Specifications for asbestos-cement pipe [10] require that the pipe be tested under hydrostatic pressure of two and one-half times the maximum working pressure for the given class of pipe. For example, samples of pipe of class 150 are required to withstand a hydraulic pressure of $375 \mathrm{lb} / \mathrm{in}^{2}$. The specifications also require that pipe sections tested by the three-edge bearing method shall not fail until the crushing load exceeds $4,600 \mathrm{lb} /$ linear $\mathrm{ft}$. for 6 -in. pipe and 5,000 lb/linear foot for 4 -in. pipe of class 150.

The effect of exposure to the various soils is seen to somewhat better advantage in figure 4, in which the differences in maximum tensile stress and modulus of rupture of the 4-in. specimens are plotted against the duration of exposure. These curves reveal definite maxima, which indicate that the increase in strength associated with the curing process is followed by a slight decrease, the magnitude of which is probably associated with the properties of the soil. Whether the indicated trends persist for greater periods of exposure or whether the reduction in strength tends to level off with time will, of course, be brought out by the data for longer exposures.

Table 5 contains the results of bursting pressure and crushing-strength tests on the unexposed 6 -in. 


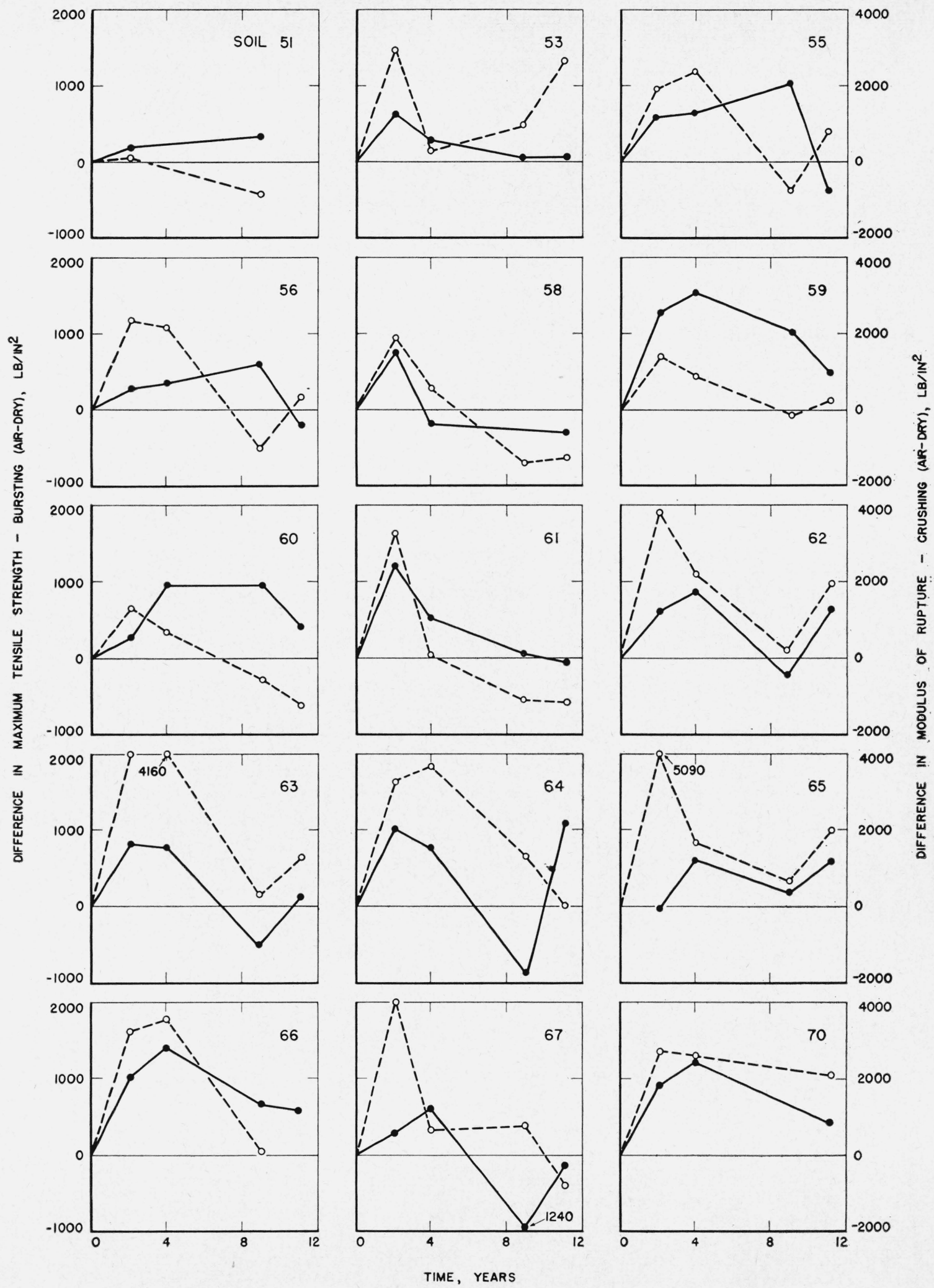

FIgURE 4. Differences in maximum tensile strength and modulus of rupture between unexposed specimens of 4-in. pipe and similar specimens exposed for different periods.

- $\quad$ Maximum tensile stress; $\bigcirc-\ldots$, modulus of rupture. 


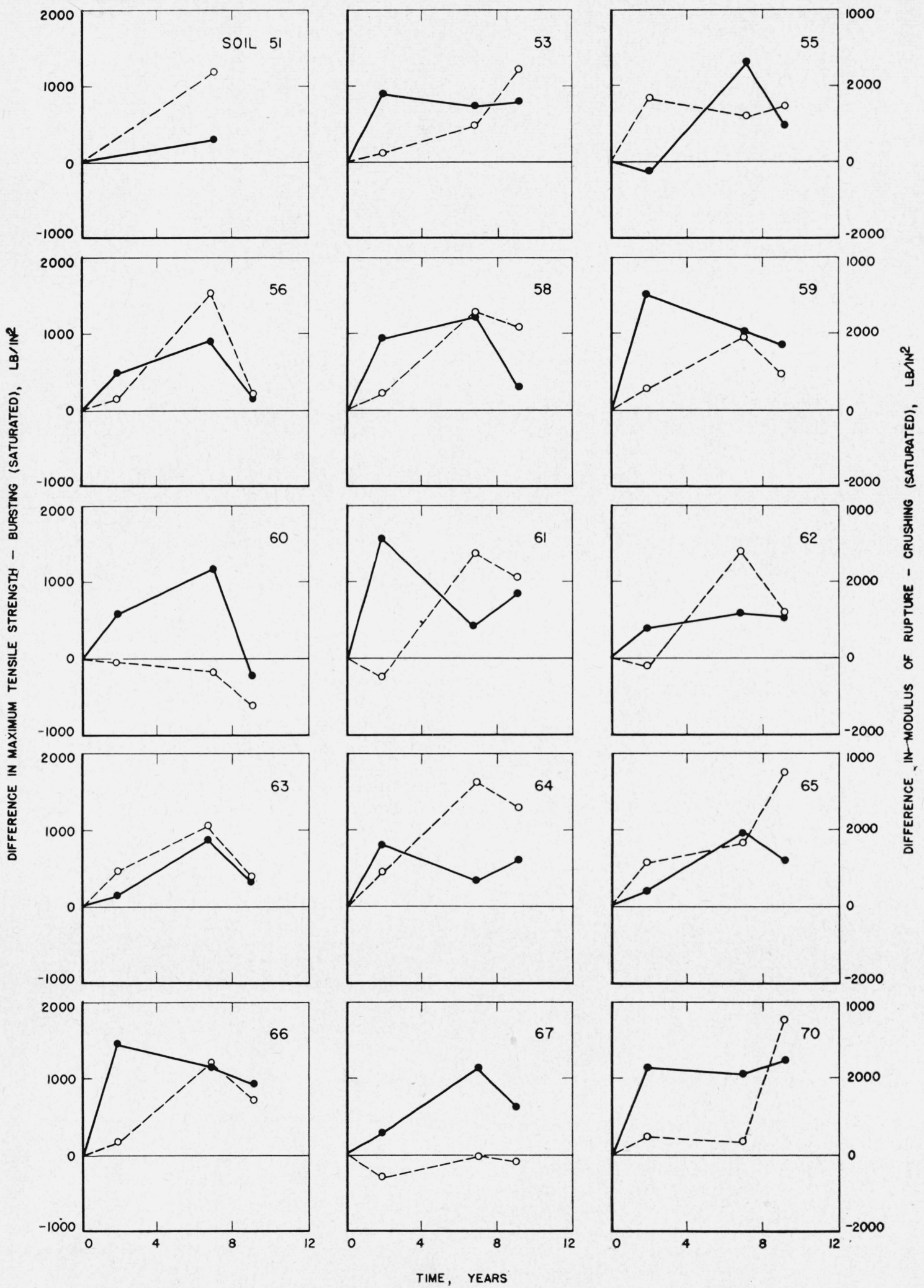

Figure 5. Differences in maximum tensile strength and modulus of rupture between unexposed specimens of 6-in. pipe and similar specimens exposed for different periods.

- - Maximum tensile stress; $\bigcirc-\cdots-\bigcirc$, modulus of rupture. 


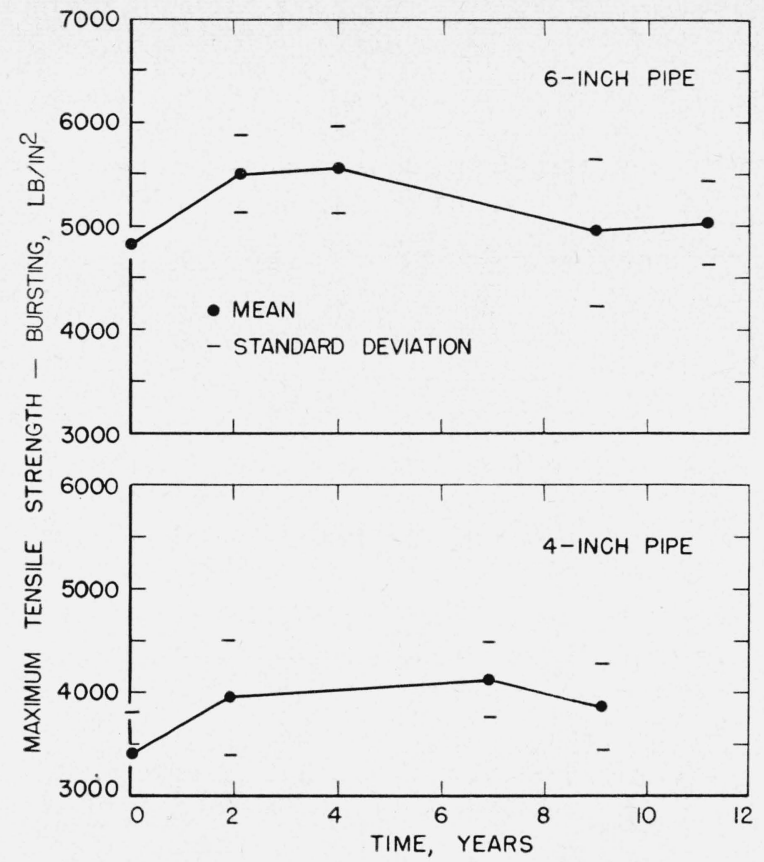

Figure 6. Average maximum tensile strength of 4-and 6-in. asbestos-cement pipe in 14 soils for various periods of exposure.

Data for both materials are based on the saturated condition.

specimens, together with the corresponding derived values for maximum tensile strength and modulus of rupture. As previously stated, unexposed specimens cut from the same lengths of 6 -in. pipe were not available. Consequently, the effect of exposure to the soils on the strengths of the 6 -in. specimens was evaluated with reference to the average values for the maximum tensile stress and modulus of rupture of the unexposed specimens recorded in table 5 .

Like the curves for the 4 -in. specimens, those in figure 5 are characterized by maxima, followed by slight reductions in strength with increasing exposure. However, no consistent trend toward progressive reduction in strength with duration of exposure is indicated.

In order to observe to somewhat better advantage the general behavior of asbestos-cement pipe exposed to soils, the values for maximum tensile strength and modulus of rupture of the 4 - and 6 -in. specimens in all of the soils were separately averaged for each period of exposure. The averages and the standard deviations ${ }^{2}$ about these averages for each exposure period are shown graphically in figures 6 and 7 . In preparing these figures, the data for the 4-in. specimens were adjusted to the water-saturated condition by reducing the values for maximum tensile strength and modulus of rupture by 15 percent, the average loss in strength resulting from saturation [7]. The data for the 6 -in. specimens show a characteristic increase in strength during the initial period of

2 With normally distributed data, approximately $95 \%$ of the values would theoretically be within an interval of plus or minus two times the standard deviation about the mean.

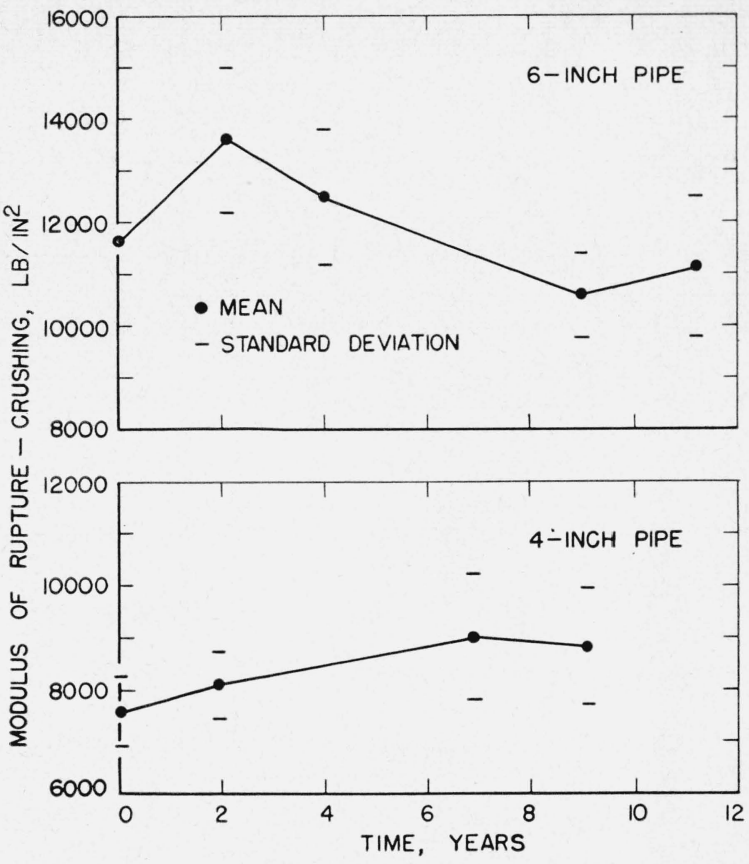

FiguRe 7. Average modulus of rupture of the 4- and 6-in. asbestos-cement pipe in 14 soils for various periods of exposure.

Data for both materials are based on the saturated condition.

exposure, followed by a slight decrease during the remaining periods. The 4 -in. specimens, on the other hand, increased in strength over the greater period of exposure, tending to decrease only after relatively long exposure. Except in the case of the data for the modulus of rupture for the 6 -in. pipe, the mean values of the exposed specimens are greater than the values for the unexposed specimens.

This difference in reaching maximum strength of the 4 - and 6 -in. specimens can be accounted for on the basis of the difference in the method of curing the two classes of material. As previously stated, the 4-in. specimens were water cured, whereas the 6 -in. specimens were steam cured. Reference had been made to the fact that steam curing of concrete masonry products results in the development of the maximum strength in a relativaly short time [6] as compared with the usual method of water curing. Consequently, it would be expected that the maximum strength of the 6-in. steam-cured specimens would be manifested relatively soon after exposure, and this effect is indicated by the data. The relatively flat curves at somewhat lower levels of strength of the 4-in. specimens are consistant with the anticipated behavior of water-cured cement products.

The curves shown in figures 6 and 7 indicate somewhat greater average strength of the 6-in. specimens throughout the maximum period for which data are available. Because of the differences in dimensions, composition of cement, and in the method of fabrication of the two varieties of pipe, the difference in strength cannot be ascribed solely to the different processes of euring. 


\subsection{Water Absorption, Apparent Specific Gravity, and Condition of Surface}

The results of the determinations of water absorption and apparent specific gravity, which were made on the 4-in. specimens after exposure to the soils, and a description of the condition of the surfaces of the specimens are given in table 6 . The differences between the amounts of water absorbed by the exposed and unexposed specimens given in the table show that almost without exception the specimens that had been dried and immersed in water after exposure to the soils for the periods indicated absorbed less water than the reference specimens. The data further show that in many cases the specimens that had been exposed for 7 years absorbed less water than the specimens that had been exposed for 2 and 9 years, respectively. Gain in apparent specific gravity tends to follow reduction in moisture absorption, the changes in both properties being greatest during the intermediate period of exposure. The occurrance of these maxima are undoubtedly associated with the curing process.
Softening of the surface of the specimens beneath the calendar layers was appreciable only at sites 60 (Rifle peat) and 67 (cinders). Even in these soils, the softening probably should be regarded as superficial, the maximum depth of softening being no greater than 0.15 in. The alkaline soils, $74,65,66$, and 70 , however, produced a reverse effect, the original porous and relatively soft external layers of the specimens exposed to all of these soils having been converted to a material of considerable hardness.

The effect of exposure to the soils on the water absorption capacity and the apparent specific gravity of the 6-in. specimens is indicated in table 7 . In the absence of reference specimens cut from the same lengths of pipe as the exposed specimens, evaluation of the effect of exposure on water absorption and apparent specific gravity is necessarily limited to comparison of the values of these properties for the individual exposed specimens with the average values for the group of reference specimens (table 5). There is a general decrease in water absorption during one or more of the earlier periods of exposure. In general this effect persisted for the maximum exposure in

TABLE 6. Water absorption, apparent specific gravity, and condition of the surface of 4-in. asbestos-cement pipe after exposure to soils

\begin{tabular}{|c|c|c|c|c|c|c|c|c|c|c|c|c|c|c|c|}
\hline \multirow[b]{2}{*}{ Soil } & \multirow[b]{2}{*}{$\begin{array}{l}\text { Expo- } \\
\text { sure }\end{array}$} & \multirow{2}{*}{$\begin{array}{c}\text { Identifi- } \\
\text { cation of } \\
\text { pipe from } \\
\text { which } \\
\text { specimen } \\
\text { was cut a }\end{array}$} & \multirow{2}{*}{$\begin{array}{l}\text { Water } \\
\text { absorp- } \\
\text { tion }\end{array}$} & \multirow{2}{*}{$\begin{array}{l}\text { Appar- } \\
\text { ent } \\
\text { specific } \\
\text { gravity }\end{array}$} & \multicolumn{2}{|c|}{$\begin{array}{l}\text { Difference from } \\
\text { unexposed }\end{array}$} & \multirow[b]{2}{*}{$\begin{array}{c}\text { Condi- } \\
\text { tion of } \\
\text { surface } b\end{array}$} & \multirow[b]{2}{*}{ Soil } & \multirow[b]{2}{*}{$\begin{array}{l}\text { Expo- } \\
\text { sure }\end{array}$} & \multirow{2}{*}{$\begin{array}{l}\text { Identifi- } \\
\text { cation of } \\
\text { pipe from } \\
\text { which } \\
\text { specimen } \\
\text { was cut a }\end{array}$} & \multirow{2}{*}{$\begin{array}{l}\text { Water } \\
\text { absorp- } \\
\text { tion }\end{array}$} & \multirow{2}{*}{$\begin{array}{l}\text { Appar- } \\
\text { ent } \\
\text { specific } \\
\text { gravity }\end{array}$} & \multicolumn{2}{|c|}{$\begin{array}{l}\text { Difference from } \\
\text { unexposed }\end{array}$} & \multirow{2}{*}{$\begin{array}{l}\text { Condi- } \\
\text { tion of } \\
\text { surface }\end{array}$} \\
\hline & & & & & $\begin{array}{l}\text { Water } \\
\text { absorp- } \\
\text { tion }\end{array}$ & $\begin{array}{l}\text { Appar- } \\
\text { ent } \\
\text { specific } \\
\text { gravity }\end{array}$ & & & & & & & $\begin{array}{l}\text { Water } \\
\text { absorp- } \\
\text { tion }\end{array}$ & $\begin{array}{l}\text { Appar- } \\
\text { ent } \\
\text { specific } \\
\text { gravity }\end{array}$ & \\
\hline $51 \ldots$ & Years & $\begin{array}{l}\mathrm{P} \\
\mathrm{I} \\
\mathrm{Q} \\
\mathrm{O} \\
\mathrm{L} \\
\mathrm{V} \\
\mathrm{T} \\
\mathrm{K}\end{array}$ & $\begin{array}{c}\text { Percent } \\
9.2 \\
13.4 \\
11.7 \\
11.6 \\
11.6 \\
9.8 \\
10.3 \\
9.7\end{array}$ & $\begin{array}{l}1.94 \\
1.82 \\
1.87 \\
1.85 \\
1.89 \\
1.92 \\
1.90 \\
1.92\end{array}$ & $\begin{array}{c}\text { Percent } \\
-5.4 \\
-4.5 \\
-4.6 \\
-5.4 \\
-4.2 \\
-4.4 \\
-2.8 \\
-6.6\end{array}$ & $\begin{array}{l}0.06 \\
.07 \\
.09 \\
.11 \\
.07 \\
.07 \\
.06 \\
.11\end{array}$ & $\begin{array}{l}2 \\
2 \\
2 \\
2 \\
2 \\
2 \\
2 \\
2\end{array}$ & $61 \ldots$ & $\begin{array}{c}\text { Years } \\
1.9 \\
6.8 \\
9.1 \\
1.9 \\
6.8\end{array}$ & $\left\{\begin{array}{c}\mathrm{E} \\
\mathrm{H} \\
\mathrm{U} \\
\mathrm{W} \\
\mathrm{Q} \\
\\
\mathrm{O} \\
\mathrm{Q} \\
\mathrm{Q}\end{array}\right.$ & $\begin{array}{c}\text { Percent } \\
13.8 \\
9.0 \\
9.3 \\
12.2 \\
12.4 \\
12.3 \\
9.8 \\
9.8\end{array}$ & $\begin{array}{l}1.85 \\
1.92 \\
1.94 \\
1.85 \\
1.85 \\
\\
1.80 \\
1.89 \\
1.92\end{array}$ & $\begin{array}{c}\text { Percent } \\
-1.8 \\
-6.9 \\
-4.6 \\
-1.8 \\
-3.9 \\
-4.7 \\
-6.5 \\
-5.8\end{array}$ & $\begin{array}{l}.02 \\
.11 \\
.07 \\
.02 \\
.07 \\
.06 \\
.11\end{array}$ & $\begin{array}{l}1 \\
2 \\
2 \\
2 \\
2 \\
\\
1 \\
1 \\
1\end{array}$ \\
\hline Avg.. & - . & ........ & 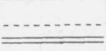 & (n. & -4.7 & .08 & 2 & & 9.1 & $\mathrm{~L}$ & $\begin{array}{l}9.8 \\
11.8 \\
10.7\end{array}$ & $\begin{array}{l}1.92 \\
1.89 \\
1.88\end{array}$ & $\begin{array}{l}-5.8 \\
-4.0 \\
-3.3\end{array}$ & $\begin{array}{l}.11 \\
.07 \\
.05\end{array}$ & $\begin{array}{l}1 \\
1 \\
1\end{array}$ \\
\hline $53 \ldots$ & $\begin{array}{l}1.9 \\
6.8 \\
9.1\end{array}$ & $\left\{\begin{array}{l}\mathrm{C} \\
\mathrm{S} \\
\mathrm{E} \\
\mathrm{V} \\
\mathrm{S}\end{array}\right.$ & $\begin{array}{r}14.4 \\
9.0 \\
9.4 \\
12.2 \\
10.3\end{array}$ & $\begin{array}{l}1.76 \\
1.94 \\
1.94 \\
1.86 \\
1.92\end{array}$ & $\begin{array}{l}-1.2 \\
-4.5 \\
-6.2 \\
-2.3 \\
-3.2\end{array}$ & $\begin{array}{r}-.05 \\
.09 \\
.11 \\
.03 \\
.07\end{array}$ & $\begin{array}{l}1 \\
1 \\
1 \\
1 \\
1\end{array}$ & $63 \ldots$ & $\begin{array}{l}1.9 \\
6.7 \\
9.0\end{array}$ & $\begin{cases}\mathrm{~L} \\
& \mathrm{E} \\
& \mathrm{E} \\
& \mathrm{U} \\
& \mathrm{L}\end{cases}$ & $\begin{array}{r}11.7 \\
9.8 \\
9.4 \\
11.1 \\
11.8\end{array}$ & $\begin{array}{l}1.88 \\
1.94 \\
1.94 \\
1.91 \\
1.88\end{array}$ & $\begin{array}{l}-4.1 \\
-5.8 \\
-6.2 \\
-2.8 \\
-4.0\end{array}$ & $\begin{array}{l}.06 \\
.11 \\
.11 \\
.04 \\
.06\end{array}$ & $\begin{array}{l}1 \\
1 \\
1 \\
1 \\
1\end{array}$ \\
\hline $55 \ldots$ & $\begin{array}{l}2.0 \\
7.1 \\
9.1\end{array}$ & $\begin{cases}\mathrm{~S} \\
\quad \mathrm{O} \\
\quad \mathrm{J} \\
\quad \mathrm{C} \\
\mathrm{F}\end{cases}$ & $\begin{array}{r}11.4 \\
13.2 \\
7.4 \\
14.0 \\
10.2\end{array}$ & $\begin{array}{l}1.78 \\
1.82 \\
1.99 \\
1.80 \\
1.93\end{array}$ & $\begin{array}{l}-2.1 \\
-3.8 \\
-8.1 \\
-1.6 \\
-5.1\end{array}$ & $\begin{array}{r}-.07 \\
.08 \\
.15 \\
.01 \\
.09\end{array}$ & $\begin{array}{l}1 \\
1 \\
1 \\
1 \\
1\end{array}$ & $64 \ldots$ & $\begin{array}{l}1.9 \\
6.9 \\
9.1\end{array}$ & $\begin{array}{l}\mathrm{J} \\
\mathrm{I} \\
\mathrm{S} \\
\mathrm{J} \\
\mathrm{L}\end{array}$ & $\begin{array}{r}10.8 \\
10.9 \\
6.3 \\
9.1 \\
9.4\end{array}$ & $\begin{array}{l}1.91 \\
1.89 \\
2.02 \\
1.96 \\
1.92\end{array}$ & $\begin{array}{l}-4.7 \\
-7.0 \\
-7.2 \\
-6.4 \\
-6.4\end{array}$ & $\begin{array}{l}.07 \\
.14 \\
.17 \\
.12 \\
.10\end{array}$ & $\begin{array}{l}1 \\
0 \\
0 \\
0 \\
0\end{array}$ \\
\hline $56 \ldots$ & $\begin{array}{l}1.9 \\
6.8 \\
9.1\end{array}$ & $\begin{array}{l}\mathrm{T} \\
\mathrm{N} \\
\mathrm{F} \\
\mathrm{N} \\
\mathrm{J}\end{array}$ & $\begin{array}{r}12.7 \\
10.9 \\
8.0 \\
13.8 \\
11.6\end{array}$ & $\begin{array}{l}1.84 \\
1.88 \\
1.99 \\
1.83 \\
1.91\end{array}$ & $\begin{array}{l}-.4 \\
-4.9 \\
-7.3 \\
-2.0 \\
-3.9\end{array}$ & $\begin{array}{l}.00 \\
.06 \\
.15 \\
.01 \\
.07\end{array}$ & $\begin{array}{l}1 \\
2 \\
2 \\
2 \\
2\end{array}$ & $65 \ldots$ & $\begin{array}{l}1.9 \\
6.9 \\
9.1\end{array}$ & $\begin{cases}\mathrm{~K} \\
\mathrm{Q} \\
\mathrm{D} \\
\mathrm{U} \\
\mathrm{B}\end{cases}$ & $\begin{array}{r}11.6 \\
9.4 \\
13.4 \\
10.9 \\
9.5\end{array}$ & $\begin{array}{l}1.85 \\
1.91 \\
1.82 \\
1.92 \\
1.95\end{array}$ & $\begin{array}{l}-4.7 \\
-6.9 \\
-4.6 \\
-3.0 \\
-4.9\end{array}$ & $\begin{array}{l}.04 \\
.13 \\
.10 \\
.05 \\
.11\end{array}$ & $\begin{array}{l}1 \\
0 \\
0 \\
0 \\
0\end{array}$ \\
\hline $58 \ldots \ldots$ & $\begin{array}{l}1.9 \\
6.8 \\
9.1\end{array}$ & $\begin{array}{l}\mathrm{V} \\
\mathrm{I} \\
\mathrm{K} \\
\mathrm{J} \\
\mathrm{T}\end{array}$ & $\begin{array}{r}12.9 \\
11.3 \\
9.5 \\
11.6 \\
12.2\end{array}$ & $\begin{array}{l}1.84 \\
1.85 \\
1.94 \\
1.90 \\
1.85\end{array}$ & $\begin{array}{l}-1.6 \\
-6.6 \\
-6.8 \\
-3.9 \\
-.9\end{array}$ & $\begin{array}{l}.01 \\
.10 \\
.13 \\
.06 \\
.01\end{array}$ & $\begin{array}{l}3 \\
2 \\
2 \\
2 \\
2\end{array}$ & $66 \ldots$ & $\begin{array}{l}1.9 \\
6.9 \\
9.1\end{array}$ & $\begin{array}{l}\mathrm{D} \\
\mathrm{I} \\
\mathrm{T} \\
\mathrm{E} \\
\mathrm{T}\end{array}$ & $\begin{array}{r}14.6 \\
9.7 \\
7.4 \\
10.6 \\
10.2\end{array}$ & $\begin{array}{l}1.80 \\
1.91 \\
1.98 \\
1.93 \\
1.91\end{array}$ & $\begin{array}{l}-3.4 \\
-8.2 \\
-5.7 \\
-5.0 \\
-2.9\end{array}$ & $\begin{array}{l}.08 \\
.16 \\
.14 \\
.10 \\
.07\end{array}$ & $\begin{array}{l}1 \\
0 \\
0 \\
0 \\
0\end{array}$ \\
\hline $59 \ldots \ldots$ & $\begin{array}{l}1.9 \\
7.0 \\
9.0\end{array}$ & $\begin{array}{l}\mathrm{U} \\
\mathrm{N} \\
\mathrm{B} \\
\mathrm{C} \\
\mathrm{S}\end{array}$ & $\begin{array}{r}12.0 \\
11.5 \\
9.3 \\
16.1 \\
14.1\end{array}$ & $\begin{array}{l}1.89 \\
1.90 \\
1.95 \\
1.76 \\
1.83\end{array}$ & $\begin{array}{r}-1.9 \\
-4.3 \\
-5.1 \\
.5 \\
.6\end{array}$ & $\begin{array}{r}.02 \\
.08 \\
.11 \\
-.05 \\
-.02\end{array}$ & $\begin{array}{l}2 \\
2 \\
2 \\
2 \\
2\end{array}$ & $67 \ldots$ & $\begin{array}{l}1.9 \\
7.0 \\
9.0\end{array}$ & $\left\{\begin{array}{l}\mathrm{O} \\
\mathrm{R} \\
\mathrm{F} \\
\mathrm{S} \\
\mathrm{Q}\end{array}\right.$ & $\begin{array}{r}12.7 \\
12.1 \\
9.3 \\
12.7 \\
17.1\end{array}$ & $\begin{array}{l}1.80 \\
1.85 \\
1.94 \\
1.85 \\
1.72\end{array}$ & $\begin{array}{r}-4.3 \\
-3.8 \\
-6.0 \\
-.8 \\
.8\end{array}$ & $\begin{array}{r}.06 \\
.06 \\
.10 \\
.00 \\
-.06\end{array}$ & $\begin{array}{l}2 \\
3 \\
3 \\
3 \\
3\end{array}$ \\
\hline $60 \ldots$ & $\begin{array}{l}1.9 \\
7.0 \\
9.0\end{array}$ & $\begin{array}{l}\mathrm{M} \\
\mathrm{G} \\
\mathrm{D} \\
\mathrm{A} \\
\mathrm{B}\end{array}$ & $\begin{array}{l}14.8 \\
13.1 \\
16.1 \\
12.4 \\
15.8\end{array}$ & $\begin{array}{l}1.79 \\
1.84 \\
1.74 \\
1.90 \\
1.79\end{array}$ & $\begin{array}{r}-1.7 \\
-3.6 \\
-1.9 \\
-1.8 \\
1.4\end{array}$ & $\begin{array}{r}-.02 \\
.04 \\
.02 \\
.05 \\
-.05\end{array}$ & $\begin{array}{l}3 \\
3 \\
3 \\
3 \\
3 \\
3\end{array}$ & $70 \ldots$ & $\begin{array}{l}1.9 \\
6.9 \\
9.1\end{array}$ & $\begin{cases} & \mathrm{~F} \\
& \mathrm{M} \\
\{ & \mathrm{D} \\
& \mathrm{R}\end{cases}$ & $\begin{array}{r}10.4 \\
8.9 \\
10.5 \\
11.3 \\
9.7\end{array}$ & $\begin{array}{l}1.90 \\
1.93 \\
1.86 \\
1.89 \\
1.93\end{array}$ & $\begin{array}{l}-4.9 \\
-7.6 \\
-7.5 \\
-4.6 \\
-3.8\end{array}$ & $\begin{array}{l}.06 \\
.12 \\
.14 \\
.10 \\
.08\end{array}$ & $\begin{array}{l}1 \\
0 \\
0 \\
0 \\
0\end{array}$ \\
\hline
\end{tabular}

a See table 3 for results of tests on reference (unexposed) specimens.

b Condition of surface: 0 , hardening of calendar layer; 1 , surface unchanged; 2 , softening to maximum depth of 0.06 in.; 3 , softening to maximum depth of 0.15 in. 
TABLE 7. Water absorption, apparent specific gravity, and condition of surface of 6-in. asbestos-cement pipe after exposure to soils ${ }^{\mathrm{a}}$

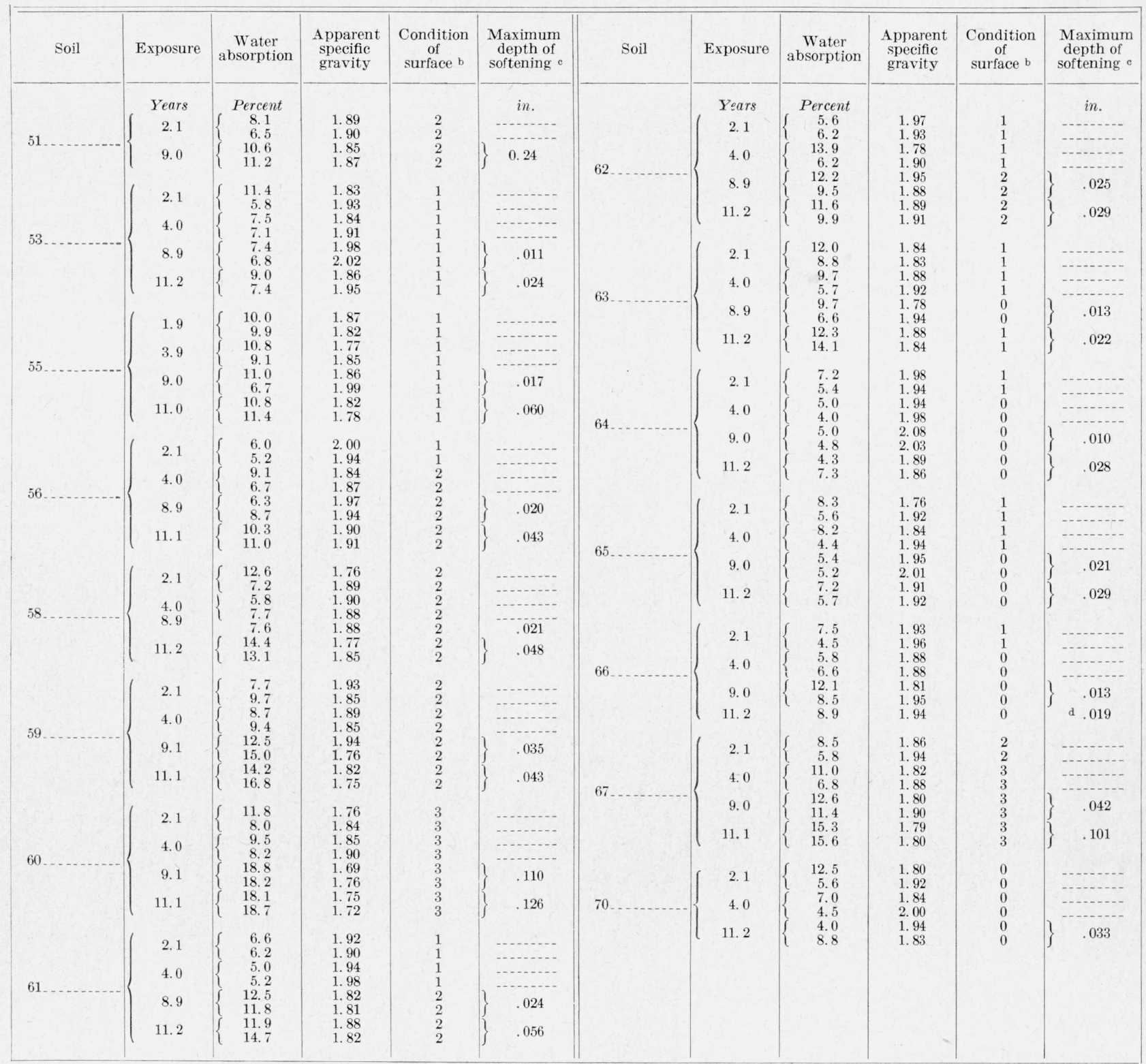

a See table 5 for results of the tests on reference (unexposed) specimens.

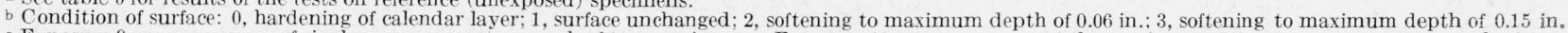

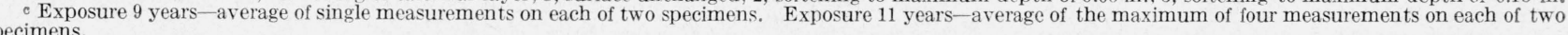
pecimens.

d One specimen only

the alkaline soils $(64,65$, and 70$)$, but in several of the other soils, notably 58, 59, 60, 61 and 67 , the amounts of water absorbed by the specimens exposed for the longer periods were greater than the average of the reference specimens.

In order to determine whether the increased amounts of water absorbed by the specimens in these soils was confined to the surface layers or whether it had penetrated to greater depths, the surfaces of the test pieces from the 11-year exposures were removed by machining to a depth of one-quarter in., and the measurement of water absorption repeated. The data summarized in table 8 , indicate that in three of the soils, 59, 61, and 63 , at least as much water was absorbed in the body of the specimen as was absorbed by the surface to a depth of one-quarter in. In the other three soils, 58, 60, and 67 , more water was absorbed in the surface layers than in the body of the material, but the quantity of water absorbed by the material as a whole was nevertheless considerable.

The condition of the surface of the 6 -in. specimens indicated in table 7 in the column headed "condition of surface" shows good agreement with the corresponding data for the 4 -in. specimens given in table 
TABLE 8. Distribution of absorbed water in 6-in. specimens (in percent)

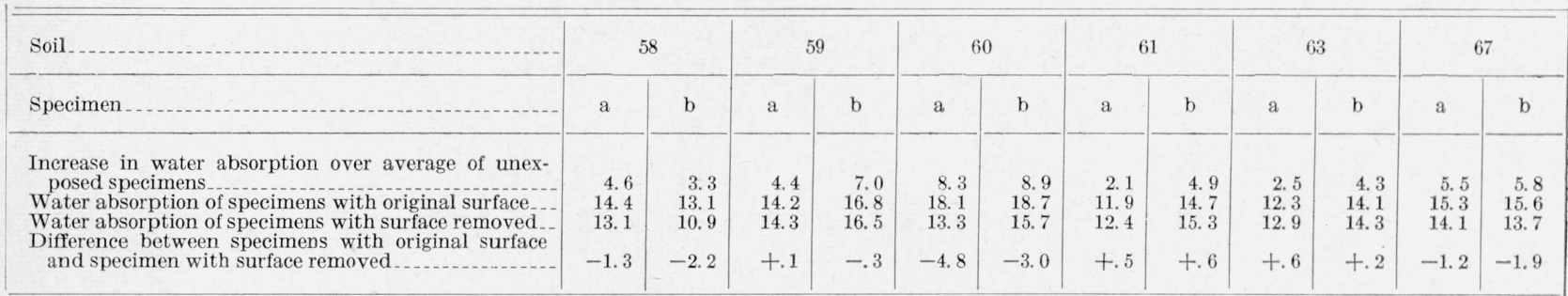

6. The maximum softening of both groups occurred in soil 60 , and both groups exhibited marked hardening of the surface in the alkaline soils.

In addition to the semiquantitative data on the condition of the surface recorded in table 7 , precise measurements of the maximum depth of softening are given for the specimens ${ }^{3}$ after exposure for 9 and for 11 years, approximately. Although these data indicate a general tendency for the depth of softening to increase with time, the maximum softening has been small (less than 0.15 in.) in relation to the wall thickness of the specimens (approximately 0.7 in.).

\section{Summary}

This report summarizes the results of measurements of the mechanical and physical properties of two varieties of asbestos-cement pipe after exposure to 15 different soils for a maximum period of 11 years. Measurements of hydrostatic bursting pressure and crushing strength showed that the maximum strength of asbestos-cement pipe was not attained until several years of exposure underground. Bursting and crushing strengths of the pipe samples, after exposure, were without exception higher than the requirements of the Federal Specifications for this class of material.

There was no definite correlation between strength and length of exposure indicated by the data for the different soil environments.

It is noteworthy that asbestos-cement pipe showed no appreciable deterioration in soils despite the known detrimental effect of high acidity, alkalinity, and high concentrations of sulfate ions toward concrete products.

Superficial softening occurred in some soils, but the depth of the softened layer was less than $0.15 \mathrm{in}$.

3 The measurements of maximum depth of softening were provided through the courtesy of the Johns-Manville Research Center.
Absorption of water was not confined to the softened layer but progressed beneath these layers. Although the measurements of softening, water absorption, and apparent specific gravity might be taken to indicate incipient deterioration of asbestos-cement pipe in some soils, in general the data for hydrostatic bursting pressure and crushing strength do not indicate actual loss in strength.

The field tests described in this paper were initiated, installed, and, until 1946, were conducted by K. H. Logan. The measurements for the more recent removals were made by Warren P. Dettmers, who also assisted in other capacities. The authors acknowledge the material assistance received from the Johns-Manville Co. and the Keasbey-Mattison Co.

\section{References}

[1] Irving A. Denison and Melvin Romanoff, J. Research NBS 44, 47 (1950) RP2057.

[2] Irving A. Denison and Melvin Romanoff, J. Research NBS 44, 259 (1950) RP2077.

[3] Kirk H. Logan, Underground corrosion, NBS Circular C450 (1945).

[4] Melvin Romanoff, J. Research NBS 34, 227 (1945) RP1639.

[5] Kirk H. Logan and Melvin Romanoff, J. Research NBS 33, 145 (1944) RP1602.

[6] Report of the Committee 716, Proc. Am. Concrete Inst. 40, 409 (1944).

[7] Clyde R. Hutcheroft, Physical and chemical characteristies of asbestos-cement pipe, Fifth NBS Soil Corrosion Conference (1943) unpublished.

[8] Report No. 425-145, Johns-Manville Research Center, Manville, N. J. (unpublished).

[9] George B. Haven and George W. Swett, The design of steam boilers and pressure vessels, p. 62 (John Wiley and Sons, Inc., New York, N. Y., 1923).

[10] Federal Specifications for Pipe: Asbestos-cement, SSP-351 (1942).

Washington, March 27, 1951 